\title{
II. Meşrutiyet Dönemi'nden Bir Mimari Temsil Örneği: Levon Güreğyan'ın 1911 Torino Uluslararası Endüstri ve Çalışma Sergisi'ndeki Osmanlı Pavyonu
}

\author{
An Example of Architectural Representation from the Second Constitutional Era: \\ The Ottoman Pavilion by Léon Gurekian at the Turin International Exhibition of \\ Industry and Labor in 1911
}

\section{Hatice Adıgüzel ${ }^{*}$}

\section{Öz}

Osmanlı Devleti, Sanayi Devrimi'nin bir sonucu olarak ortaya çıkan uluslararası sergilere 1851 Londra Sergisi'nden itibaren katılmaya özen göstermiştir. Sultan II. Abdülhamid döneminde, Batı’ya karşı modern bir toplum ve İslam dünyasının lideri görüntüsü sunma idealiyle, bu katılımlar yoğunlaşarak farklı bir boyut kazanmıştır. II. Meşrutiyet Dönemi'nde de Osmanlı hükümeti bu sergilerin bir parçası olmaya devam etmiştir.

Bu makale, II. Meşrutiyet Dönemi’nde Osmanlı Devleti'nin katıldığı 1911 Torino Uluslararası Endüstri ve Çalışma Sergisi'ne odaklanmaktadır. Makale, ağılıklı olarak Osmanlı Arşivi'nde konuyla ilgili bulunan belgeler ve İtalya'da serginin gerçekleştiği dönemde yapılan yayınların değerlendirilmesiyle hazırlanmıştır. Yapılan araştırmalar sonucunda, Osmanlı́nın 1911 Torino sergisine katılım süreci, arka plandaki aktörleri, inşa edilen pavyonun mimari ve üslup özellikleri, mimarı gibi konularda tespitler ortaya konulmuştur. Bu sergi için inşa edilen Osmanlı pavyonu mimar Levon Güreğyan tarafından tasarlanmıştır. Bilinen görsel verilerine ek olarak, pavyonun Güreğyan imzalı planı ilk kez bu çalışmada tanıtılmaktadır. Pavyon, Osmanlı'da Birinci Ulusal Mimarlık Akımının egemen olduğu bir dönemde Oryantalist üslubuyla dikkat çekmektedir. Çalışmada Oryantalist üslubun bu geç örneğinin Osmanlı'da Tanzimat sonrası oluşan milli mimari kimliği ile ilişkisi tartışılmaktadır.

\section{Anahtar Kelimeler}

Uluslararası sergiler, Torino, Osmanlı-ïtalya İlişkileri, II. Meşrutiyet, Levon Güreğyan

\begin{abstract}
The Ottoman Empire took care to attend the international exhibitions that emerged because of the Industrial Revolution, beginning from the first event organized in London in 1851. During the reign of Sultan Abdülhamid II, this involvement increased in line with the idea of presenting a modern society and the leader of the Islamic world to the West. The Ottoman government continued to be a part of these exhibitions during the Second Constitutional Era. This paper focuses on the Turin International Exhibition of Industry and Labor 1911, which the Ottoman Empire attended during the Second Constitutional Era. The paper is largely based on an evaluation of relevant documents obtained from the Ottoman Archives and Italian publications from that period. Studies revealed information on the Ottoman participation in Turin International
\end{abstract}

* Sorumlu Yazar: Hatice Adıgüzel (Dr. Öğr. Gör.), İstanbul Üniversitesi, Güzel Sanatlar Bölümü, İstanbul, Türkiye. E-posta: ahatice@istanbul.edu.tr ORCID: 0000-0001-8511-9219

Atıf: Adiguzel, Hatice. “II. Meşrutiyet Dönemi’nden Bir Mimari Temsil Örneği: Levon Güreğyan’ın 1911 Torino Uluslararası Endüstri ve Çalışma Sergisi'ndeki Osmanlı Pavyonu." Art-Sanat, 17(2022): 1-33.

https://doi.org/10.26650/artsanat.2022.17.1002343 
1911, actors in the background, architectural and stylistic characteristics of the pavilion, and the architect, Léon Gurekian. In addition to known visual data, the plan of the pavilion signed by Gurekian is introduced in this paper for the first time. The pavilion stands out with an Orientalist style during a period dominated by the First National Architectural Movement in the Ottoman Empire. The paper discusses the relationship of this late example of the Orientalist style with the Ottoman national architectural identity that emerged after the Tanzimat reform period.

\section{Keywords}

International exhibitions, Turin, Ottoman-Italian Relations, Second Constitutional Era, Léon Gurekian

\section{Extended Summary}

International exhibitions have been organized in the Western world from the mid$19^{\text {th }}$ century onwards because of the industrialization and the search for new markets. The Ottoman Empire took care to attend these exhibitions, beginning from the first event organized in London in 1851, in parallel with the industrialization and modernization programs of the Tanzimat Era. Participating countries in international exhibitions would exhibit their national architectural identities in addition to their industrial technologies and products, especially following the Paris exhibition of 1867 . The Ottoman Empire attended these exhibitions with an architectural representation in keeping with the image of the "East" in the Western imagination. Within this context, a sort of Islamic eclecticism was devised by a combination of architectural shapes gathered from Ottoman structures from the past and European-oriented Orientalist elements (mostly from Maghreb-Andalusia). This Orientalist style also manifested itself on buildings erected within the empire's borders and constituted the character of Ottoman pavilions at international exhibitions.

Ottoman participation in international exhibitions took a new form during the long reign of Abdülhamid II as the purpose of presenting a modern society and the leader of the Islamic world to the West gained strength. This period saw a high level of participation in international exhibitions, mostly by building a pavilion. The Ottoman Empire tried to be a part of international exhibitions during the Second Constitutional Era, albeit at a lower scale. The architectural manifestation of the changing ideology with constitutionalism was named the First National Architectural Movement. While this style was preferred in the official buildings built in many parts of the state, it is seen that the Orientalism that emerged after the Tanzimat continued to be used in the Ottoman architectural representations at the international exhibitions of this period.

Although there is a large body of research on the $19^{\text {th }}$ century Ottoman participation in international exhibitions, limited research exists on exhibitions with Ottoman participation in the early $20^{\text {th }}$ century. This paper addresses Ottoman participation in the Turin International Exhibition of Industry and Labor in 1911. The paper is largely based on an evaluation of relevant documents obtained from the Ottoman Archives and Italian publications from that year. Studies revealed information on the Ottoman 
participation in the exhibition, which has not been studied in detail yet, as well as actors in the background, architectural and stylistic characteristics of the pavilion built in Turin, and the architect.

Turin International Exhibition of Industry and Labor 1911 was among the events marking the $50^{\text {th }}$ establishment anniversary of the Kingdom of Italy. As part of the celebrations, international exhibitions were organized in Turin, Florence, and Rome, which served as capitals of the kingdom after 1861. The Ottoman Empire initially planned to participate in Rome and Turin exhibitions. Many documents are available in the Ottoman Archives related to the preparations for these attendances. The Ottoman Embassy in Rome and the Ministry of Trade and Public Works assumed principal roles in organizing the exhibitions. To encourage participation, officials from the embassy in Rome penned various letters, which provide information on locations where exhibitions were planned, participating countries, as well as dimensions, costs, and styles of the pavilions.

The Ottoman government, possibly due to concerns such as time constraints and financial difficulties, withdrew from the Rome exhibition in late 1910, and only attended the Turin exhibition with a pavilion. In February 1911, Ali Riza Bey, Consul of Ancona, was appointed as the Ottoman commissioner of the Turin exhibition. Construction of the Ottoman pavilion was completed around the same time. The pavilion was designed by Léon Gurekian, an Ottoman architect who was born in Istanbul, studied architecture in Rome and designed and constructed buildings in Istanbul and Sofia. He moved to Rome with his family in 1907. The fact that Gurekian had demonstrated his architectural ability with buildings he produced in Istanbul, had a grasp of Ottoman architecture, and resided in Italy must have been factors when the Ottoman government commissioned him to design the pavilion.

Photos of the Ottoman pavilion designed by Léon Gurekian were printed in Italian publications from the exhibition period, Ottoman newspapers and various postcards. In 2010, Armen Gurekian, grandson of Léon Gurekian, published a watercolor perspective drawing of the pavilion. Within the context of this study, the ground floor plan of the pavilion was obtained in the Ottoman Archives. According to this plan which is introduced in this study for the first time and additional images of the structure, the pavilion had a square plan. The exterior mass was in the shape of an Ottoman mansion with Orientalist characteristics in style. It is understood that a document found in the Ottoman Archives and submitted to the Ottoman government helped determine the style. This document is a letter signed by Seyfeddin Bey, who worked as an undersecretary at the embassy in Rome during the period of exhibition preparations and was appointed as commissioner of the Turin exhibition before Ali Riza Bey, and relays general information on the exhibitions in Rome and Turin. In this 
letter, Seyfeddin Bey also expresses an opinion, proposing that the Ottoman pavilion as a representative structure should stand out with "magnificent architecture" and decorations, like the Green Mosque in Bursa. In this paper, the Orientalist structure designed by Gurekian, which was possibly inspired by this proposal, is associated with the Ottoman architectural discourse that emerged after the Tanzimat. The paper discusses the significance of the Green Mosque and other early Ottoman buildings in the concept of "national architecture", which was created during the late Tanzimat era. Moreover, this pavilion example reveals that the Orientalist style was still in use in Ottoman architectural representations at international exhibitions during a period dominated by the First National Architectural Movement. The architectural repertoire implemented by Léon Gurekian in Istanbul indicates a familiarity with this style on his part. Therefore, this paper emphasizes that the tendencies of architects as well as patrons and the elite class guiding them were determinant factors during the selection of style for buildings. 


\section{Giriş}

19. yüzyılın ikinci yarısında, Batı ülkelerinde endüstrinin gelişmesine paralel olarak uluslararası sergiler düzenlenmiştir. Bu sergiler, sanayi teknolojileri ve ürünleri, bilim ve sanat eserlerinin yanında, özellikle 1867 Paris sergisinden itibaren, katılımc1 ülkelerin milli mimari kimliklerinin de sergilendiği yerler olmuştur. Osmanlı Devleti, Tanzimat Dönemi'nin sanayileşme ve modernleşme programları paralelinde, Avrupa ve Amerika'da düzenlenen uluslararası sergilere 1851 Londra Sergisi'nden itibaren katılmaya itina etmiştir. Özellikle II. Abdülhamid döneminde bu katılımlar farklı bir boyut kazanmıştır. Bu dönemde bir yandan gelişmekte olan Osmanlı sanayisini tanıtma amacı güdülürken diğer yandan Batı'ya karşı uygar bir toplum ve İslam dünyasının lideri görünümü sunma amacıyla sergi katılımları yoğunlaşmıştır. ${ }^{1} 1888$ Barcelona, 1889 Paris, 1893 Chicago, 1894 Anvers, 1896 Budapeşte, 1897 Brüksel, 1900 Paris, 1902 Torino, 1904 St. Louis² ve 1905 Liege, II. Abdülhamid döneminde gerek ayrı pavyon inşa ederek gerekse ana sergi binaları içinde yer alarak katılım sağlanan başlıca sergiler olmuştur. ${ }^{3}$ Toprak kayıpları ve küçülen ekonomisine rağmen Osmanlı Devleti II. Meşrutiyet Dönemi'nde de uluslararası sergilere katılmaya devam etmiştir. 1910 Brüksel, 1911 Torino, 1914 Lyon ve 1915 Panama sergileri bunlar arasındadır.

Osmanlı Devleti'nin 19. yüzyıl uluslararası sergilerine katılımı pek çok araştırmanın konusu olurken, yüzyıl dönümünden sonraki sergiler genellikle bu kapsamın dışında bırakılmıştır. Bu makale, şimdiye kadar hakkında detaylı araştırma yapılmayan 1911 yılında Torino'da düzenlenen Uluslararası Endüstri ve Çalışma Sergisi'ne odaklanmaktadır. Makale, ağırlıklı olarak, arşiv belgeleri ve dönem kaynaklarından yararlanılarak hazırlanmıştır. 1911 Torino Uluslararası Sergisi hakkında genel bilgiler, Osmanlıların bu sergiye katılım süreci, sergideki Osmanlı pavyonunun mimari ve üslup özellikleri, pavyonun tasarımcısı, az tanınan bir Osmanlı mimarı olan Levon Güreğyan'ın kimliği makale kapsamında değerlendirilmektedir.

\section{Torino Uluslararası Endüstri ve Çalışma Sergisi}

1911 yılında İtalya Krallı̆̆ı'nın kuruluşunun 50. yılı kutlamaları nedeniyle uluslararası sergiler düzenlenmiştir. ${ }^{5}$ III. Vittorio Emanuele döneminde gerçekleştirilen bu

\footnotetext{
1 Osmanlı Devleti'nin katıldığı uluslararası sergiler hakkında kapsamlı olarak bk. Zeynep Çelik, Şarkın Sergilenişi 19. Yüzyıl Dünya Fuarlarında İslam Mimarisi (İstanbul: Tarih Vakfı Yayınları, 2005); Nurcan Yazıcı, "Uluslararası Sergilerde Osmanlı Mimarisi’nin Sunumu," Arkitekt 500 (2004), 18-30; Aytaç Işıkl1, Türkiye Fuar Albümü: Osmanlı Dönemi (İstanbul: İstanbul Fuar Merkezi Yayınları, 2012); Gökhan Akçura, Türkiye Sergicilik ve Fuarcllık Tarihi (İstanbul: Tarih Vakfı Yayınları, 2009).

2 Sevil Derin, "1904 St. Louis Dünya Fuarı ve Osmanlı Temsiliyeti: Celal Esad Arseven Sergisi," Art-Sanat 13 (2020), 87-116.

3 Selim Deringil, İktidarın Sembolleri ve İdeoloji: II. Abdülhamid Dönemi (1876-1909) (İstanbul: Doğan Kitap, 2014), 171-182.

4 Mimarın ismi Batı dillerinde "Léon Gurekian" olarak geçmektedir.

5 John Allwood, The Great Exhibitions (London: Studio Vista, 1977), 115.
} 
sergiler için, krallığın kurulduğu 1861 yılından itibaren devlete başkentlik yapmış olan Torino, Floransa ve Roma şehirleri seçilmiştir. Sergilerin hazırlıklarına 1907 y1lında başlanmıştır. Roma sergisi, genel olarak güzel sanatlar ve arkeoloji konularına adanmıştır. Bu sergi şehrin farklı noktalarında bulunan çeşitli mekânlarda düzenlenmiştir. Bunlar içinde, güzel sanatlara ayrılan ana bölüm Valle Giulia bölgesinde yer almıştır. Diocletianus Hamamları ve Sant'Angelo Kelesi gibi mevcut yapılar içinde farklı içeriklerde sergiler açılmıştır. Piazza d'Armi'de bulunan ve Roma sergisi kapsamında tamamlanan Vittorio Emanuele Anıtı'nın içinde de sergilemeler yapılmıştır. Floransa sergisi ise, İtalyan portreleri ve botanik konularına adanmıştır. İtalyan portreleri sergisi Palazzo Vecchio'da, botanik sergisi Giardino dell'Orticoltura'da düzenlenmiştir. ${ }^{6}$

"Uluslararası Endüstri ve Çalışma Sergisi (Esposizione internazionale dell'industria e del lavoro )" başlıklı Torino'daki sergi ise, adından da anlaşılacağı gibi, daha çok sanayi, teknoloji ve çalışma üzerine odaklanmıştır. Nitekim eski Savoy Dükalığı'nın merkezi olan Torino'nun, sergi mekânı olarak seçilmesinin bir diğer nedeni, İtalya Krallığı'nın endüstri başkenti olarak tanınmasıydı. Torino'da ana temalar çerçevesinde eğitim ve öğretim, savunma, endüstri, tarım, ticaret, bilim ve teknik, elektrik, yollar ve demiryolları, şehirleşme, spor gibi alanlarda sergiler düzenlenmiştir. ${ }^{7}$ Roma sergisi güzel sanatlara adandığı için Torino'da bu alanda sergileme yapılmamıştır. Ancak sanat ve endüstri arasında köprü görevi gören dekoratif ve uygulamalı sanatlara ait eserler Torino pavyonlarında teşhir edilmiştir. ${ }^{8}$

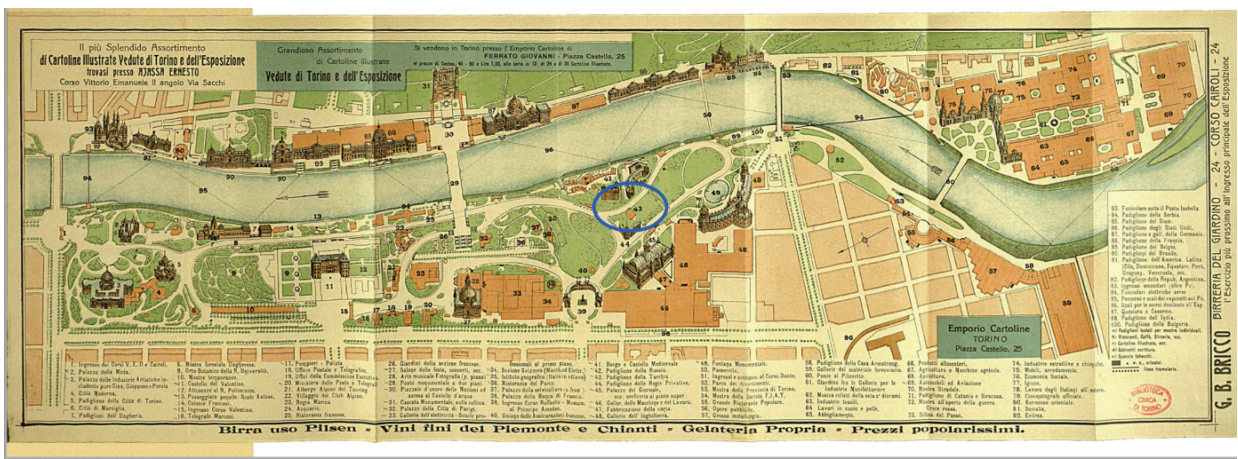

G. 1: 1911 Torino Uluslararası Endüstri ve Çalışma Sergisi genel planı. Lejantta 43 numara Osmanlı pavyonunu göstermektedir (Guida Pratica della Esposizione Internazionale di Torino, 1911).

6 Mariantonietta Picone Petrusa, Maria Raffaela Pessolano ve Assunta Bianco, Le Grandi Esposizioni in Italia 1861-1911: La Competizione Culturale con l'Europa e la Ricerca dello Stile Nazionale (Napoli: Liguori, 1988), 118, 122-123, 128. Bu üç şehirdeki sergiler hakkında kapsamlı olarak ayrıca bk. Le Esposizioni del 1911: Torino, Roma, Firenze (Milano: Fratelli Treves, 1911); Le Esposizioni di Roma e di Torino nel 1911 Descritte ed Illustrate, 10 (Milano: Società Editrice Sonzogno, 1911).

7 Maria Cristina Buscioni, Esposizioni e "Stile Nazionale” (1861-1925): Il Linguaggio dell'Architettura nei Padiglioni Italiani delle Grandi Kermesses Nazionali ed Internazionali (Firenze: Alinea Editrice, 1990), 241.

8 Petrusa, Pessolano ve Bianco, Le Grandi Esposizioni in Italia 1861-1911: La Competizione Culturale con l'Europa e la Ricerca dello Stile Nazionale, 120. 
29 Nisan-19 Kasım tarihleri arasında açık kalan Torino sergisi, Po Nehri’nin Batı kıyısı boyunca uzanan Valentino Park1 ${ }^{9}$ merkez olacak şekilde düzenlenmiştir. Daha sonraki süreçte, sergi alanı parkın karşı kıyısında, Umberto I Köprüsü’nden Borgo del Pilonetto’ya kadar uzanan alana kadar genişletilmiştir. Toplamda 1.200.000 metrekarelik bir alana yayılan sergi alanının yaklaşık 380.000 metrekaresi inşa edilecek binalara ayrılmıştır (G. 1). Geçmişin uluslararası sergilerinde olduğu gibi belli başlı ülkeler bu sergi kapsamında Torino’ya davet edilmiştir. Fransa, İngiltere, Almanya, İsviçre, Belçika, Macaristan, Bulgaristan, Sırbistan, Rusya, Arjantin, Venezuela, Brezilya, Uruguay, Dominik, Ekvator, Panama, Peru, Fransız Kolonileri, Amerika, Osmanlı Devleti, İran, Siyam Krallığı (Tayland) ve Çin sergiye katılan ülkeler olmuştur. ${ }^{10}$

Torino sergisinin düzenleme komisyonu başkanlığını Tommaso Villa yapmıştır. Serginin genel tasarımı Giacomo Salvadori di Wieshenoff, Stefano Molli ve Pietro Fenoglio tarafından gerçekleştirilmiştir. ${ }^{11}$ Sergi binalarının genel üslubu Neo-Barok olarak seçilmişti. Bu tercih için Torino’nun 17. ve 18. yüzy1l mimarisinden ilham alınmıştı. Barok canlandırmacılığının (revivalizm) tercih edilmesinin çeşitli anlamları vardı. Bu üslup hem şehrin başkent olduğu yılların ihtişamını hatırlatıyor hem de Roma'nın görkemli mimarisine rakip olabilecek hareketliliği sunuyordu. ${ }^{12}$ Sergi binalarını tek üslup altında toplama fikri için 1893 Chicago Kolomb Dünya Sergisi'nden esinlenilmişti. ${ }^{13}$ Bilindiği gibi Chicago sergisinin düzenleme komitesi tüm binaların yapımını üstlenmiş ve onları tek bir üslup altında birleştirmişti. Bununla birlikte, Torino sergisinde bazı yabancı ülkelerin özellikle doğu Avrupa, orta ve uzak doğu ülkelerinin pavyonları birbirinden farklı üsluplarda tasarlanmıştı. Serginin yürütme komitesi, katılımcı ülkelere kendi estetik zevklerini özgürce kullanma izni vermişti. Böylece bazı ülkeler "milli mimari” imajlarını sergileme imkânı bulmuştu. Örneğin, "İmparator Atilla’nın Çadır-Sarayı" adını taşıyan Macaristan pavyonu, Art Nouveau esintileri taşıyan kübik, modern bir kütle ile Macar yerel ögelerini birleştirmiş, Orta

9 Bu park 1911 Torino sergisinin yanı sıra, 1884, 1898, 1902 ve 1928 uluslararası sergilerine de ev sahipliği yapmıştır. 1884 sergisi kapsamında (Esposizione Italiana Agricola e Industriale) parkta, belli başlı yapılarıyla canlandırılan temsili bir Orta Çağ Köyü (Borgo Medievale) inşa edilmiştir. Bu bölüm günümüzde müze olarak kullanılmaktadır. Kapsamlı bilgi için bk. "Dall'Esposizione al Museo," Borgo Medievale, erişim 16 Eylül 2021, http://www.borgomedievaletorino.it/il-borgo/come-nasce-borgo-medievale/da-esposizione-a-museo/ .

10 Petrusa, Pessolano ve Bianco, Le Grandi Esposizioni in Italia 1861-1911: La Competizione Culturale con l'Europa e la Ricerca dello Stile Nazionale, 118, 120. Katılımcı ülkelerin pavyonları ve sergilemeleri hakkında ayrica bk. Guida Pratica della Esposizione Internazionale di Torino, 1911 (Torino: Ajassa \& Ferrato Editori, 1911); Pasquale De Luca, “All’Esposizione Internazionale di Torino," Emporium 34/ 199 (1911), 37-52; Pasquale De Luca, "L'Arte all'Esposizione di Torino," Emporium 34/202 (1911), 271-289; "Participating Countries," Turin 1911: The World's Fair in Italy, erişim 16 Eylül 2021, https://italyworldsfairs.org/ basic/NS/Nation States .

11 Guida Ufficiale della Esposizione Internazionale:Torino 1911 (Torino: Stabilimento Tipografico Dott. G. Momo, 1911), 60; Petrusa, Pessolano ve Bianco, Le Grandi Esposizioni in Italia 1861-1911: La Competizione Culturale con l'Europa e la Ricerca dello Stile Nazionale, 119.

12 Petrusa, Pessolano ve Bianco, Le Grandi Esposizioni in Italia 1861-1911: La Competizione Culturale con l'Europa e la Ricerca dello Stile Nazionale, 119.

13 Buscioni, Esposizioni e "Stile Nazionale" (1861-1925): Il Linguaggio dell'Architettura nei Padiglioni Italiani delle Grandi Kermesses Nazionali ed Internazionali, 245. 
Asya çadırını anımsatan görünümüyle öne çıkmıştı. Sırbistan pavyonu ise Neo-Bizans üslubuyla dikkat çekmişti. ${ }^{14}$ Siyam Krallığı'nın binası ise pagoda benzeri çatılarıyla diğerlerinden ayrılmıştı. ${ }^{15}$ Osmanlı Devleti’nin pavyonu da bu sıra dışı örnekler arasindayd1.

\section{Osmanlı Devleti’nin 1911 Torino Uluslararası Endüstri ve Çalışma Sergisi’ne Katılımı}

Osmanlı Devleti'nin Tanzimat Dönemi'nde oluşan sanayileşme girişimleri II. Meşrutiyet Dönemi'nde daha sağlam temellere oturmaya başlamıştır. Dönemin hâkim düşüncesi olan "Türk Ulusçuluğu” ekonomiye de yansımış, Alman iktisadi düşüncesinden esinlenilerek "milli iktisat" politikası benimsenmiştir. ${ }^{16}$ 1908-1918 dönemi, Osmanlı' da sanayileşme bilincinin oluştuğu yıllardır. Bu dönemde sanayi teşvik kanunu tasarıları hazırlanmış, sanayi mektepleri açılmış, Dersaadet Ticaret Odası Gazetesi, Türk Yurdu gibi gazete ve dergilerde sanayileşme sorunları tartış1lmış, sanayiyi teşvik adına sergi ve panayırlar açılmıştır. 1909 yılında Bursa' da açılan sergi bunların başında gelmektedir. ${ }^{17}$ Öte yandan bu dönemde gelişmekte olan Osmanlı sanayisinin teşviki ve uluslararası pazarda tanıtımı adına yurt dışındaki sergilere de katılım sağlanmıştır. 1911 yılında Torino’da düzenlenen sergi bunlardan biridir.

Osmanlı Devleti, İtalya Krallığı'nın kuruluşunun 50. yılı kutlamaları vesilesiyle Roma ve Torino'da düzenlenen sergilere katılmayı planlamıştır. Türkiye Cumhuriyeti Cumhurbaşkanlığı Devlet Arşivleri Başkanlığı Osmanlı Arşivi’nde bu sergilere katılma hazırlıklarına dair çok sayıda belge bulunmaktadır. Resmi yazışmalar, söz konusu sergilere katılım fikrinin Şubat 1908 tarihinden itibaren ${ }^{18}$ hükümetin gündeminde olduğunu ortaya koymaktadır. Roma’daki Osmanlı sefareti ile İstanbul'daki Ticaret ve Nâfia Nezareti bu sergilerin organizasyonunu sağlamada başlıca görevi üstlenmiştir. Roma sefaretinden sergiye hükümetin katılımını teşvik etmek için çeşitli yazılar yazılmıştır. 1909 yılında, Roma Büyükelçisi İbrahim Hakkı Bey’in ${ }^{19}$ yazdığı yazılar bu

14 Söz konusu pavyonlar için bk. De Luca, “All’Esposizione Internazionale di Torino,” 48, 55-56; "Participating Countries," https://italyworldsfairs.org/basic/NS/Nation_States .

15 Siyam pavyonu Torinolu mimarlar Annibale Rigotti ve Mario Tamagno tarafından tasarlanmıştır. Bunlardan Rigotti 1893-1896 yılları arasında İstanbul'da Raimondo D'Aronco ile çalışmış, 20. yüzyıl başlarında ise Siyan Krallığı'nda mimari aktivitelerde bulunmuştur. Giorgio Rigotti, 80 Anni di Architettura e di Arte: Annibale Rigotti Architetto 1870-1968, Maria Rigotti Calvi Pittrice 1874-1938 (Torino: Tipografia Torinese Editrice 1980), 19-20, 113.

16 Şevket Pamuk, Osmanll-Türkiye İktisadi Tarihi 1500-1914 (İstanbul: İletişim Yayınları, 2017), $226-227$.

17 Zafer Toprak, Türkiye'de Milli İktisat 1908-1918 (İstanbul: Türkiye İş Bankası Kültür Yayınları, 2019), 3548, 242-253.

18 Başkanlık Osmanlı Arşivi (BOA), Hariciye Nezareti İdare (HR.İ.) 1225/39-1, M 12 Şubat 1908.

191 Ocak 1909-28 Aralık 1909 arasında Roma Büyükelçiliği yapan, daha sonra sadrazam olan İbrahim Hakk1 Bey/Paşa hakkında bk. İbnülemin Mahmut Kemal İnal, Osmanlı Devrinde Son Sadrazamlar (İstanbul: Dergah Yayınları, 1982), 4: 1763-1804; Zekeriya Kurşun, "İbrahim Hakkı Paşa (1863-1918) Osmanlı Sadrazamı," TDV İslâm Ansiklopedisi, c. 21 (İstanbul: Türkiye Diyanet Vakfı Yayınları, 2000), 311-314. 
bağlamda önemlidir. 3 Şubat 1909 tarihli bir yazısında ${ }^{20}$ her iki sergiye de katılmanın milli bir sorumluluk olduğunun altını çizmiştir. Özellikle sanayi ve sanayi ürünlerinin teşhirine yönelik olan Torino sergisine katılmanın iki devlet arasındaki ticari bağları güçlendireceğini vurgulamıştır. Daha önce düzenlenen Viyana ${ }^{21}$ ve Chicago sergilerinde Osmanlı ürünlerinin tanıtılmasının ticaret üzerinde çok büyük etkisi olduğunu ifade etmiştir. Kendisinin komiser olarak bulunduğu Chicago sergisinde ${ }^{22}$ tanıtılan sanayi ürünlerinin ve özellikle halıların gördügü ilgiden ve bunun sonucunda alınan madalyalardan söz etmiştir. Hükümetin bu sergiye resmen iştirak etmesinin, "diğer büyük devletler gibi” bir şube açmasının, ticari ilişkilerin güçlenmesi adına, mutlaka gerekli olduğunu açıklamıştır.

İbrahim Hakkı Bey'in bu önerisi Osmanlı hükümeti tarafindan uzun süre cevapsız bırakılmıştır. Büyükelçi daha sonra yazdığı çeşitli yazılarla, 3 Şubat tarihli önerisinin cevapsız kalmasından yakınarak Bâb-1 Âli’nin bu konudaki fikrinin ne olduğunu sormuştur. 19 Haziran 1909'da yazdığı bir yazıda, İtalyanlar'ın bu sergiye milli bir mesele olarak baktığının, Avusturya hükümetinin katılım konusunda çekimser kalmasının İtalya hükümetince büyük şaşkınlıkla karşılandığının, Osmanlı Devleti'nin de bu duruma düşmemesi için biran önce katılma kararı alıp tarafına bildirilmesinin gerekliliğini vurgulamıştır. ${ }^{23} \mathrm{Bu}$ arada 1909 yılının sonuna doğru İbrahim Hakkı Bey Roma büyükelçiliğinden ayrılarak sadrazam olmuş, yerine 30 Ocak 1910 tarihinde Hüseyin Kazım Bey atanmışıı.ı. ${ }^{24}$ Osmanlı hükümetinin bu sergilere katılımının resmileşmesi ise 1910 baharını bulmuştur. Roma büyükelçilerinin tüm 1srarları sonucunda, 10 Nisan 1910 tarihinde Osmanlıların her iki sergiye de iştirak edeceği Meclis'te karara bağlanmıştır. ${ }^{25}$ Aynı günkü toplantıda, hem Roma hem de Torino sergilerinin komiserliğine, bu görevi fahri olarak üstlenmeyi teklif eden, Gergoes Vaxelaire (belgelerde yazdığı şekliyle "Mösyö Jorj Vakseler") ${ }^{26}$ getirilmiştir. Söz konusu yazılarda belirtildiği gibi, bu kişi “Devleti Aliyye'nin Brüksel fahri şehbenderi” olup, 1910 Brüksel sergisindeki Osmanlı şubesinin komiserliğini de üstlenmiştir. ${ }^{27}$ Daha sonraki

20 Başkanlık Osmanlı Arşivi (BOA), Hariciye Nezareti İdare (HR. İD.) 1225/34-1, M 3 Şubat 1909. Hariciye Nezareti'ne Fransızca yazılan bu yazının Osmanlıca çevirisi için bk. Başkanlık Osmanlı Arşivi (BOA), Bab-1 Ali Evrak Odası (BEO) 3806/285423-8, M 3 Şubat 1909.

21 Söz konusu yazıda Viyana sergisinin tarihi hatalı olarak "1868” şeklinde belirtilmiştir. Bilindiği gibi Viyana Uluslararası Sergisi 1873 yılında düzenlenmiştir.

22 Chicago sergisi hakkında kapsamlı olarak bk. Bengi Başaran, “1893 Chicago Kolomb Dünya Sergisi’nde Osmanlı Temsili,” (Doktora Tezi, İstanbul Teknik Üniversitesi, 2015).

23 Başkanlık Osmanlı Arşivi (BOA), Hariciye Nezareti İdare (HR.ID.) 1225/34-7, M 19 Haziran 1909.

24 Hüseyin Kazım Bey Washington Büyükelçiliği’nden Roma Büyükelçiliği’ne tayin edilmiş, Trablusgarp Savaşı'nın başlamasına kadar bu görevini sürdürmüştür. Bk. Sinan Kuneralp, "Palazzo Gamberini'den Osmanlı-İtalyan İlişkilerine Bir Bakış,” Palazzo Gamberini: Türkiye’nin Roma Büyükelçiliği, haz. Arzu Karamani Pekin (İstanbul: Vehbi Koç Vakfi, 2013), 30.

25 Başkanlık Osmanlı Arşivi (BOA), Meclis-i Vükela Mazbataları (MV.) 139/17-1, H 29 Rebiulevvel 1328/ R 28 Mart 1326 (10 Nisan 1910).

26 Başkanlık Osmanlı Arşivi (BOA), Bab-1 Ali Evrak Odası (BEO) 3733/ 279934, R 4 Safer 1328 (16 Şubat 1910).

27 BOA, MV.139/17-1. 
süreçte, Torino sergisinin komiserliğine Roma sefareti müsteşarı Seyfeddin Bey tayin edilmiş̧ir. Ancak Seyfeddin Bey sıhhi nedenlerle 2 Şubat 1911 tarihinde bu görevden istifa etmiştir. ${ }^{28}$ Akabinde, İtalyancaya hakimiyeti tercih sebebi olan Ancona ${ }^{29}$ Şehbenderi Ali Rıza Bey komiserliğe atanmıştır. ${ }^{30}$

Seyfeddin Bey'in henüz komiserliğe atanmadan ${ }^{31}$ ve Osmanlı Devleti'nin katılım kararı belirlenmeden önce, Hariciye Nezareti'ne yazdığı iki yazısından Roma ve Torino sergilerine hükümetin katılımı konusunda dikkat çekici bilgilere ulaşılmaktadır. 23 Ocak 1910 tarihinde yazdığı ilk yazıda ${ }^{32}$ Torino'daki komiteden henüz haber alamadığını, bu nedenle, öncelikle, Roma sergisiyle ilgili bilgileri aktardığını belirtmiştir. Yazıya göre, sergiye katılan her ülkeye pavyon inşası için farklı boyutlarda arazi ayrılmıştır. Bu durum, ülkelerin sergileyecekleri sanayi ürünlerinin önemine göre değişmektedir. Öte yandan, özellikle "sanayisi güçsüz olan bazı ülkelere" sergi binalarını kendi yerel mimarlarına tasarlatma olanağ 1 verilmiştir. Böylece, söz konusu ülkeler, sanayi ürünleriyle olmasa da sergi mahalline taşıyacakları milli mimari kimlikleriyle dikkat çekebileceklerdir. Ancak bu yerel mimarların hazırlayacağı planlar İtalyan genel sergi komitesi tarafından onaylanacaktır. Seyfeddin Bey yazısında, hükümetin bu sergiye katılımı hâlinde, Osmanlı pavyonunun üslubu konusunda da fikirlerini beyan etmiştir. Yazısında, Osmanlı pavyonunun Bursa Yeşil Cami gibi "muhteşem bir mimariye sahip" camilerden birini temsilen inşa edilmesini önermiştir. Bununla birlikte binanın "Avrupalıların çok hoşuna giden nefis çinilerle süslenmesi hâlinde" 33 sergide iyi bir intiba bırakılacağının altını çizmiştir.

Seyfeddin Bey daha sonra, Torino sergi komitesinden aldığı haber doğrultusunda buradaki sergi ile ilgili bilgileri aktaran bir yazı daha yazmışır. ${ }^{34} 29$ Ocak 1910 tarihli bu yazıda, Torino sergisi ile ilgili genel bilgileri verdikten sonra, bu sergiye katılan bazı ülkelerin pavyonlarını inşa edecekleri alanlardan söz etmiştir. Buna göre, İngiltere 32000, Fransa 12000, Almanya 9500, Belçika 5000, Macaristan 2000, Siyam ise 300 metrekarelik alanlarda pavyonlarını kuracaktır. Eğer Osmanlı Devleti bu sergiye katılmak isterse, Po Nehri'nin "sağ"35 tarafinda 3000 ile 4000 metrekare arasında ücretsiz

28 Başkanlık Osmanlı Arşivi (BOA), İrade Meclis-i Mahsus (İ. MMS.) 136/7-1, H 7 Safer 1329 / R 25 Kanunisani 1326 (7 Şubat 1911).

29 Ancona, İtalya'nın Adriyatik Denizi kıyısında bulunan bir liman kentidir.

30 Başkanlık Osmanlı Arşivi (BOA), Dahiliye İdare (DH.ID.)108/11-1, R 2 Şubat 1326 (15 Şubat 1911).

31 Hüseyin Kazım Bey 30 Ocak 1910 tarihinde görevine başlamıştır. Söz konusu yazı, Seyfeddin Bey’in müsteşar olarak büyükelçiliğe vekalet ettiği sırada yazılmış olmalıdır.

32 Başkanlık Osmanlı Arşivi (BOA), Hariciye Nezareti İdare (HR.ID.) 1225/38-1, M 23 Ocak 1910. Fransızca olan bu yazının Osmanlı Türkçesine tercümesi için bk. Başkanlık Osmanlı Arşivi (BOA), Bab-1 Ali Evrak Odası (BEO) 3733/ 279934-5, R 23 Kanunisani 1910 (23 Ocak 1910). Söz konusu çeviride ay kısmı Rumi, yıl kısmı Miladi takvime göre yazılmıştır.

33 BOA, HR.İD.1225/38-1.

34 Başkanlık Osmanlı Arşivi (BOA), Hariciye Nezareti İdare (HR.İD.) 1225/38-2, M 29 Ocak 1910.

35 Valentino Parkı, Po Nehri'nin eski şehir dokusunun bulunduğu kıyıdadır. Bu yazıda "sağ taraf" olarak kastedilen yer, parkın karşısı yani nehrin Doğu kıyısı olmalıdır. 
olarak alınabilecek yerler hâlâ mevcuttur. Nehrin "şehir tarafındaki kıyısında" ise hiç boş yer kalmamıştır. Seyfeddin Bey Torino komitesinden aldığı bilgilere göre, pavyonları inşa edecek şirketi bulmanın zor olmadığını, işçilik ücretinin metrekare başına 40-60 İtalyan lireti arasında olduğunu ifade etmiş̧ir. Ek olarak Torino sergisinin genel planını da gönderdiğini belirtmesine rağmen, Osmanlı Arşivi'ndeki bu yazı takımında söz konusu plana ulaşılamamıştır. Seyfeddin Bey sözlerini, Osmanlı hükümetinin katılma kararının bir an önce bildirilmesi, geç kalınması hâlinde inşaatın daha pahalıya mal olacağını ifade ederek tamamlamıştır. Bu yazıda belirtmese de Seyfeddin Bey'in ilk yazısında ${ }^{36}$ Roma sergisi için önerdiği Osmanlı şubesinin mimari üslubu Torino için de geçerli olmalıdır. 10 Nisan 1910 tarihinde, Meclis’te bu sergilere katılımın karara bağlandığı yazıda, "her iki şehirde tarz-1 millîye muvafik sûrette" inşa edilecek binaların resim, kroki ve haritalarının Ticaret ve Nâfia Nezareti'nin onayına sunulması yönünde bir ifade kullanılmıştır. ${ }^{37}$ İlk etapta her iki şehirde kurulacak Osmanlı şubelerinin inşası için ise, komiser maaşı da dâhil, 3000 küsur lira bütçe ayrılmıştır. ${ }^{38}$

Bütün bu hazırlıklara rağmen, Roma sergisi için inşası planlanan Osmanlı pavyonu son anda yapılan bir karar değişikliğiyle iptal edilmiştir. ${ }^{39} 11$ Aralık 1910 tarihinde Sadaret'ten Maliye Nezareti'ne yazılan bir yazıda, Roma sergisine katılacak diğer devletlerin pavyonlarının inşası bitmek üzere olduğu hâlde, Osmanlı şubesine henüz başlanmadığ 1 vurgulanmış ve bu meselenin bir an önce halledilmesi istenmiştir. ${ }^{40}$ İptal kararı, bu yazıdan da anlaşıldığı gibi, hem zaman kısıtlılığı hem de ekonomik nedenlerle alınmış olmalıdır. Daha sonra, başlangıçta her iki sergi için ayrılan 3000 küsur lira ${ }^{41}$ Ocak/Şubat 1911 tarihi bir yazıdan anlaşıldığına göre yalnızca Torino sergisine tahsis edilmiştir. ${ }^{42}$

Torino sergisi için planlanan Osmanlı pavyonu bütün gecikmelere rağmen inşa edilmiştir. Arşiv belgelerinden ve Torino'da sergi boyunca basılan süreli yayınlardan anlaşıldığına göre, 1911 yılının ilk aylarında söz konusu pavyonun inşası tamamlanmıştır. ${ }^{43} 13$ Şubat 1911 tarihinde, son sergi komiseri Ali Rıza Bey’in hazırladığı bir talimatname hem Torino sergisinin düzeni hem de binası ile ilgili önemli verileri

36 BOA, HR.İD.1225/38-1.

37 BOA, MV.139/17-1.

38 Başkanlık Osmanlı Arşivi (BOA), Bab-1 Ali Evrak Odası (BEO) 3835/287570-2, H 27 Zilhicce 1328/R 16 Kanunuevvel 1326 (30 Aralık 1910).

39 Petrusa, Pessolano ve Bianco, Le Grandi Esposizioni in Italia 1861-1911: La Competizione Culturale con l'Europa e la Ricerca dello Stile Nazionale, 124.

40 Başkanlık Osmanlı Arşivi (BOA), Bab-1 Ali Evrak Odası (BEO) 3834/287489-1, H 8 Zilhicce 1328/R 27 Teşrinievvel 1326 (11 Aralık 1910).

41 BOA, BEO 3835/287570-2.

42 Başkanlık Osmanlı Arşivi (BOA), İrade Meclis-i Mahsus (İ. MMS.) 136/7-2, H Muharrem/Safer 1329 / R Kanunisani 1326 (Ocak/Şubat 1911).

43 Le esposizioni di Roma e di Torino nel 1911 descritte ed illustrate, 79. Mart 1911 tarihli bu süreli yayında, Osmanlı sergi binasının geç de olsa tamamlandığından, mimarından, üslubundan ve sergi komitesiyle ilgili bazı detaylardan bahsedilmektedir. 
aktarmaktadır. Talimatnamede, öncelikli olarak Osmanlı üretimlerinin hangi koşullarda ve nereye gönderileceğine dair bilgiler bulunmaktadır. Yazıda, sergideki Osmanlı bölümünün oldukça iyi bir konumda, "önemli ülkelerin" pavyonlarının yanında ve 400 metrekarelik bir alana sahip olduğundan bahsedilmektedir. ${ }^{44}$ Osmanlı hükümeti katıldığı uluslararası sergilerde itibarlı bir yer edinme konusuna daima özen göstermiştir. İslam dünyasının lideri olma idealiyle Osmanlılar, sanayi önderi ülkelerle bir arada olmayı arzu etmiştir. Örneğin 1893 Chicago sergisinin III. Ahmed Çeşmesi’ni model alan Osmanlı sergi binası, Torino'daki sergi ile aynı ölçülerdeki (400 metrekare) bir alanda kurulmuştur. Bununla birlikte, devletin onuruna yakışacak bir konumun ayarlanması için bakanlarla sergi komitesi arasında yazışmalar yapılmıştır. ${ }^{45} 1900$ Paris sergisinde Osmanlı Pavyonu ilk defa oldukça prestijli bir yerde, Amerika ve İtalya pavyonları arasında yer almıştır. ${ }^{46} \mathrm{Bu}$ anlamda diğer İslam devletlerinden "daha önemli” bir konumda, Batılı ülkelerin bir parçası gibi sunulmuştur. 1911 Torino sergisi için Ali Rıza Bey'in sözünü ettiği “önemli ülkeler” ise İngiltere ve Rusya'dır. ${ }^{47}$ Bunlardan, özellikle sanayide lider konumundaki İngiltere ile yan yana olmak Osmanlılar için oldukça önemli olmalıdır. Öte yandan, daha önce Seyfeddin Bey 29 Ocak 1910 tarihli yazısında Po Nehri'nin şehir tarafında pavyon inşası için yer kalmadığından söz etmişti. ${ }^{48}$ Oysa, Torino sergisinin genel planına bakıldığında (G. 1) bahsi geçen bu "önemli ülkeler" ile birlikte Osmanlı pavyonunun nehrin şehir tarafında inşa edildiği görülmektedir. Demek ki daha sonraki süreçte sergi komitesi, ölçüleri küçük de olsa daha prestijli bir yer elde etmeyi başarabilmiştir.

Ali Rıza Bey'in yazısının devamında, Torino sergisine gönderilecek sanayi ürünlerinin kolilerle gönderilme şartları sıralanmaktadır. Uluslararası bir jürinin sergiye katılan ürünleri inceleyeceği ve başarılı olanlara ödül vereceği yazıda belirtilmiştir. Derecelerine göre 1. büyük ödül, 2. altın madalya, 3. gümüş madalya, 4. bronz madalya alacaktır. "Piazza Solferino, No. 3-Turin (Italie)" gönderim adresi olarak talimatnamenin altına yazılmıştır. Üretimlerin yerleştirileceği kutulara yapıştırılacak etiketlerin örneği yazı ekinde sunulmuştur (G. 2). Ekte ayrıca bir de sergiye katılım formu bulunmaktadır (G. 3). 20 Mart'ta Dahiliye Nezareti aracılığıyla Osmanlı esnaf ve tüccarlarına bir tebligat yapılarak Nisan'ın 29'unda açılacak Torino sergisine çok az zaman kaldığı hâlde, Osmanlı şubesinin büyük bir bölümünün boş olduğu vurgulanmış, gönderilecek sanayi ürünlerinin bir an evvel belirtilen adrese gönderilmesi istenmiştir. ${ }^{49}$ Ayrıca, serginin açılışında Osmanlı şubesinin boş kalmasının "ecnebiye

44 Başkanlık Osmanlı Arşivi (BOA), Dahiliye İdare (DH.İD.) 108/11-7, M 13 Şubat 1911.

45 Deringil, İktidarın Sembolleri ve İdeoloji: II. Abdülhamid Dönemi (1876-1909), 172.

46 Yeşim Duygu Ergüney ve Nuran Kara Pilehvarian, “Ondokuzuncu Yüzyıl Dünya Fuarlarında Osmanlı Temsiliyeti," Megaron 10/2 (2015), 238-239.

47 Guida Pratica della Esposizione Internazionale di Torino, 1911, 49.

48 BOA, HR.İD. 1225/38-2.

49 Başkanlık Osmanlı Arşivi (BOA), Dahiliye İdare (DH.İD.) 108/11-3, R 7 Mart 1327 (20 Mart 1911). Aynı belge grubunda Dahiliye Nezareti'nin yaptığı 15 Şubat 1911 tarihli bir tebligat daha bulunmaktadır. 
karşı" kötü bir etki bırakacağının altı çizilmiştir. Sergi komiseri Ali Rıza Bey hazırladığı talimatnamenin ekinde Osmanlı pavyonunun planı da yer almaktadır (G. 6). Plan Osmanlı mimarı Levon Güreğyan imzasını taşımaktadır.

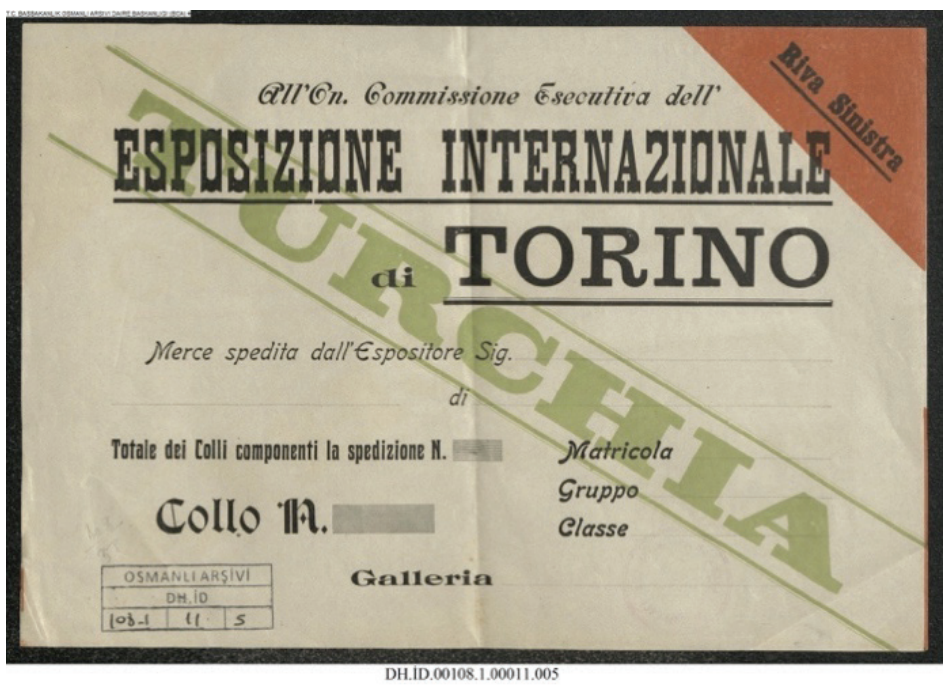

G. 2: 1911 Torino sergisine Osmanlı Devleti’nden gönderilecek üretimler için etiket örneği (BOA, DH.İD. 108/11)

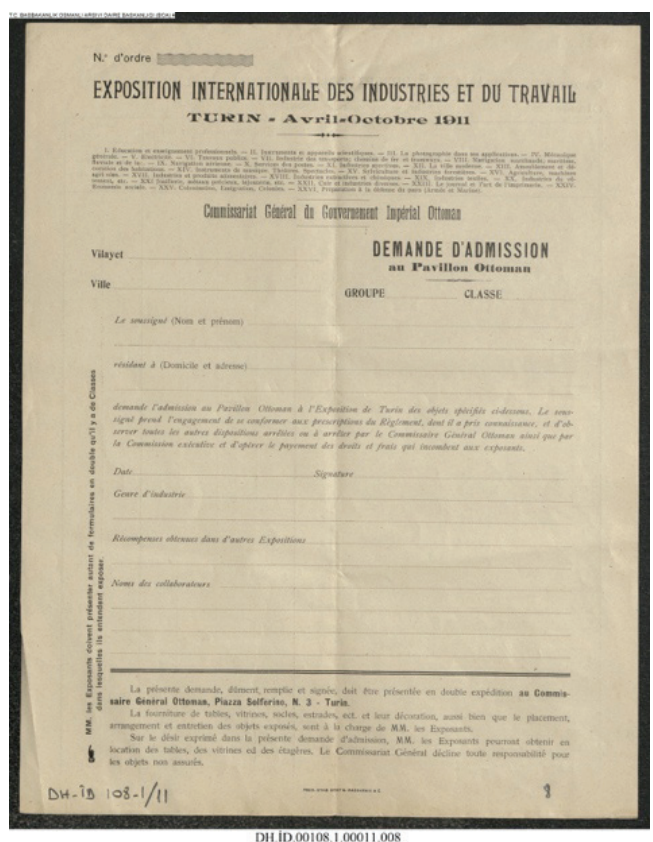

G. 3: 1911 Torino sergisi için Osmanlı esnaf ve tüccarları tarafından kullanılacak katılım formu (BOA, DH.İD. 108/11) 
Torino sergisinin resmi aç1lışı 29 Nisan tarihinde gerçekleşmiş olsa da Osmanlı binasındaki teşhirin açılışının 10 Haziran'ı bulduğu İtalyan kaynaklarından birinde belirtilmektedir. ${ }^{50}$ Sergi, Osmanlı hanedanını temsilen Veliaht Şehzade Yusuf İzzeddin Efendi ${ }^{51}$ tarafından ziyaret edilmiştir. İzzeddin Efendi hem sergiyi gezmek hem de iki devlet arasındaki ilişkileri güçlendirmek adına Londra seyahatinin ardından İtalya'ya geçmiştir. ${ }^{52} 29$ Haziran'da Torino'ya ulaşmış, 30 Haziran günü ise şehirde düzenlenen uluslararası endüstri ve çalışma sergisini gezmiştir. Yusuf İzzeddin Efendi, yeşilliğiyle göz kamaştıran Valentino Parkı'nda düzenlenmiş sergi alanını gezerken kendisini İstanbul Boğazı'nda hissettiğini belirtmiştir..$^{53} 2$ Temmuz 1911 tarihinde Roma'ya giden İzzeddin Efendi, ertesi gün İtalya Kralı III. Vittorio Emanuele ile birlikte Roma fuarının farklı mekânlarda düzenlenen sergilerini ziyaret etmiştir. Bunlar içinde, özellikle Diocletianus Hamamlarındaki arkeoloji sergisi ile Sant'Angelo Kalesi'ndeki retrospektif sergiye ${ }^{54}$ özel ilgi göstermiştir. ${ }^{55}$

\section{Üç Ülke Arasında Aktif Bir Mimar: Levon Güreğyan (1871-1950)}

Torino sergisi için inşa edilen Osmanlı pavyonunun tasarımcısı mimar Levon Güreğyan'ın yaşamı ve yapıtları hakkındaki en detaylı bilgiler torunu Armen Güreğyan'ın hazırladığı kitapta bulunmaktadır. ${ }^{56}$ Kendisi de mimar olan Armen Bey söz konusu kitapta dedesinin detaylı hayat hikâyesini ve görselleriyle birlikte eserlerinin bir listesini yayımlamıştır.

Levon Güreğyan 26 Nisan 1871 tarihinde İstanbul'da doğmuştur ${ }^{57}$ (G. 4). Trabzonlu bir tüccar aileye mensuptur. Trabzon'da bir Mıkhitarist rahipler okulunda aldığı ön eğitiminin ardından, ailesi tarafından Venedik'e, Moorat Raphael Koleji'nde okumak üzere gönderilmiştir. Buradaki eğitimini 1888 yılında tamamlayarak tekrar Trabzon'a dönmüştür. Bir yıl sonra Roma'ya giderek Kraliyet Güzel Sanatlar Enstitüsü'ne (Re-

50 Le Esposizioni del 1911: Torino, Roma, Firenze, 212.

51 Sultan Abdülaziz'in oğlu olan Yusuf İzzeddin Efendi, V. Mehmed Reşad döneminde "Veliahd-1 Saltanat" sıfatıyla yurt içi ve yurt dışında devleti temsil etmek amacıyla çeşitli seyahatlerde bulunmuştur. İzzeddin Efendi küçüklüğünde babası Abdülaziz'in 1867'deki Paris seyahatine de katılmıştır. Bk. Necdet Sakaoğlu, "Yusuf İzzeddin Efendi," Yaşamlarl ve Yapıtlarlyla Osmanlılar Ansiklopedisi, c. 2 (İstanbul: Yapı Kredi Yayınlar1, 1999), 683-684.

52 Kuneralp, "Palazzo Gamberini’den Osmanlı-İtalyan İlişkilerine Bir Bakış,” 35-37; Ali Akyıldız, "Yusuf İzzeddin Efendi," TDV İslâm Ansiklopedisi, c. 44 (İstanbul: Türkiye Diyanet Vakfı Yayınları, 2014), 15.

53 Le Esposizioni del 1911: Torino, Roma, Firenze, 255, 269.

$54 \mathrm{Bu}$ sergiler hakkında detaylı bilgi için bk. Petrusa, Pessolano ve Bianco, Le Grandi Esposizioni in Italia 1861-1911: La Competizione Culturale con l'Europa e la Ricerca dello Stile Nazionale; Buscioni, Esposizioni e "Stile Nazionale” (1861-1925): Il Linguaggio dell'Architettura nei Padiglioni Italiani delle Grandi Kermesses Nazionali ed Internazionali.

55 Le Esposizioni del 1911: Torino, Roma, Firenze, 269.

56 Armen Gurekian, Léon Gurekian Architetto (Treviso: G. S. Stampa di Asolo, 2010).

57 Armen Güreğyan'ın kitabında mimarın doğum yılı 1871 olarak belirtilmiştir. Bk. Gurekian, Léon Gurekian Architetto, 9; Kevork Pamukciyan ise doğum tarihini 1869 olarak vermektedir. Bk. Kevork Pamukciyan, Ermeni Kaynaklarından Tarihe Katkılar-IV: Biyografileriyle Ermeniler (İstanbul: Aras Yayınc1lık, 2003), 231 . 
gio Istituto di Belle Arti) kaydolmuştur ve bu okuldan 1895 'te mimari tasarım profesörü lisansı almıştır. Aynı yıl Kraliyet Mühendislik Uygulama Okulu'nun (Regia Scuola di Applicazione per gli Ingegneri) mimarlık alanından mezun olmuş (G. 5) ve 1896 yılında İstanbul'a dönmüştür. Ancak burada milliyetçi olayların yarattığı karışık bir ortamla karşılaşmış, ardından Sofya'ya gitmek durumunda kalmıştır. Sofya' da mimari çalışmalarını sürdürmüş, birkaç bina tasarlamıştır. 1898 yılında, Varna Belediye Tiyatrosu için düzenlenen uluslararası yarışmada birinci olmuştur. ${ }^{58}$ Aynı yıl İstanbul'a dönmüştür. 1898-1907 yılları arasında, İstanbul içinde ve Adalar'da, kamu ve özel kişiler için birçok yapı tasarlamış ve uygulamıştır. ${ }^{59}$ Annuaire Oriental yıllıklarına göre Güreğyan 1896-1909 yılları arasında İstanbul'da mimar olarak faaliyet göstermiştir. ${ }^{60}$ Buradan yola çıkılarak Sofya'da ve daha sonra İtalya'da olduğu süreçte İstanbul ile iş bağlantılarını sürdürdüğü sonucuna ulaşılabilir. ${ }^{61}$ Y 11 lıklardan anlaşıldığı kadarıyla İstanbul'da çalıştığı dönemdeki iş adresi zaman içinde değişiklik göstermiştir. Önce Beyoğlu-Kabristan Sokak No: 16'da, daha sonra Karaköy, Gümrük Sokak'ta bulunan Çeçeyan (Tchetcheyan) Han’da, 20 ve 21 numaralı odalarda çalışmıştır. Son olarak Voyvoda Caddesi, Agopyan Han (Eski Baltazzi Han), 11 numaralı oda, iş adresi olarak gözükmektedir. Bununla birlikte, Büke Uras, Güreğyan'ın Sofya öncesinde Sarkis Balyan'ın mimarlık bürosunda çalıştığını belirtmektedir. ${ }^{62}$

58 Bu yarışmaya, 1893-1896 yılları arasında İstanbul'da Raimondo D'Aronco ile birlikte çalışan Torinolu mimar Annibale Rigotti de katılmıştır. Ancak ikisinin projeleri arasında belirgin farklar vardır. Bk. Gurekian, Léon Gurekian Architetto, 25; Rigotti, 80 Anni di Architettura e di Arte: Annibale Rigotti Architetto 1870-1968, Maria Rigotti Calvi Pittrice 1874-1938, 64. İki mimar daha sonra 1911 Torino sergisi için çalışmış, Güreğyan Osmanlı Devleti'nin, Rigotti ise (Mario Tamagno ile) Siyam Krallı̆̆ı'nın pavyonunu tasarlamıştır. Söz konusu mimarların İtalya, Osmanlı ve Bulgaristan ekseninde, aynı dönemlerde kesişen yolları ilgi çekicidir.

59 Gurekian, Léon Gurekian Architetto, 9.

60 Annuaire Oriental du Commerce de L'industrie, de L'administration et de la Magistrature (Constantinople: Cervati Freres \& Cie, 1896), 630; Annuaire Oriental du Commerce de L'industrie, de L'administration et de la Magistrature (Constantinople: Cervati Freres \& Cie, 1898), 631; Annuaire Oriental du Commerce de L'industrie, de L'administration et de la Magistrature (Constantinople: The Annuaire Oriental \& Printing Company Limited, 1900), 382, 631; Annuaire Oriental du Commerce de L'industrie, de L'administration et de la Magistrature (Constantinople: The Annuaire Oriental \& Printing Company Limited, 1901), 651; Annuaire Oriental du Commerce de L'industrie, de L'administration et de la Magistrature (Constantinople: The Annuaire Oriental \& Printing Company Limited, 1902), 731; Annuaire Oriental du Commerce de L'industrie, de L'administration et de la Magistrature (Constantinople: The Annuaire Oriental \& Printing Company Limited, 1903) 438, 799; Annuaire Oriental du Commerce de L'industrie, de L'administration et de la Magistrature (Constantinople: The Annuaire Oriental \& Printing Company Limited, 1904), 507, 1020; Annuaire Oriental du Commerce de L'industrie, de L'administration et de la Magistrature (Constantinople: The Annuaire Oriental \& Printing Company Limited, 1909), 602, 1049.

61 Hasan Kuruyazıcı Annuaire Oriental ticaret yıllıklarını tarayarak İstanbul'un unutulmuş mimarlarıyla ilgili elde ettiği sonuçlarda Levon Güreğyan'a da yer vermiştir. Bk. Hasan Kuruyazıcı, “İstanbul'un Unutulmuş Mimarları-4," İstanbul 34 (2000), 75. Burada Güreğyan'ın İstanbul'da çalıştığı son yıl olarak 1921 gösterilmiştir. Annuaire Oriental'in 1921 yıllığında Güreğyan'ın adı meslekler kısmında değil, yalnızca adresler kısmında geçmektedir. Annuaire Oriental du Commerce de L'industrie de L'administration et de la Magistrature, (Constantinople: Alfred Rizzo, 1921), 380. Kendisi 1921 yılında İstanbul'a iki ay süreyle gelmiştir. Ancak bu süreçte mimarlık görevi yapıp yapmadığı belirsizdir. Gurekian, Léon Gurekian Architetto, 5.

62 Büke Uras, Balyanlar: Osmanlı Mimarlı̆̆l ve Balyan Arşivi (İstanbul: Korpus Kültür ve Sanat Yayıncılık, 2020), 29. 


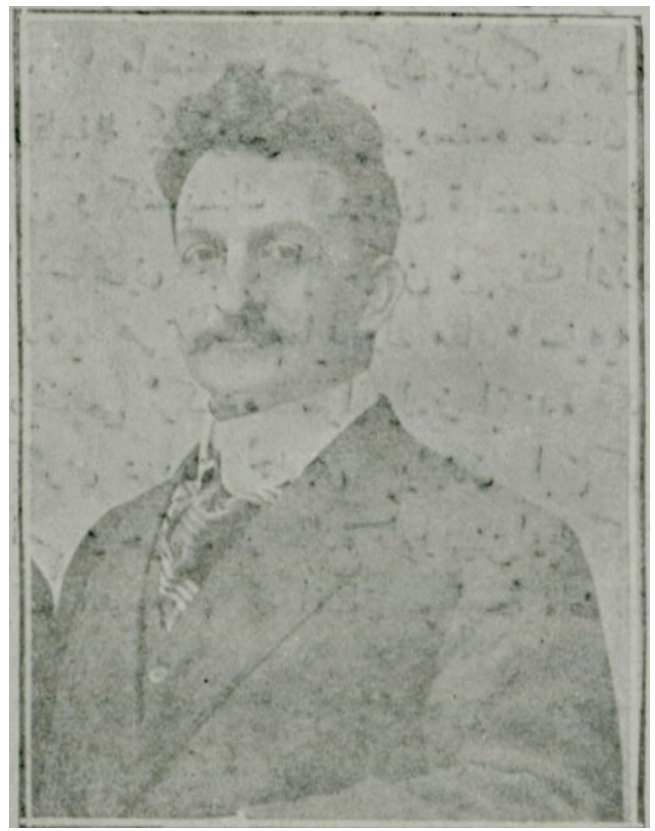

G. 4: Levon Güreğyan fotoğrafi (Şehbal 39, R 1 Mayıs 1327 (14 Mayıs 1911), 297)

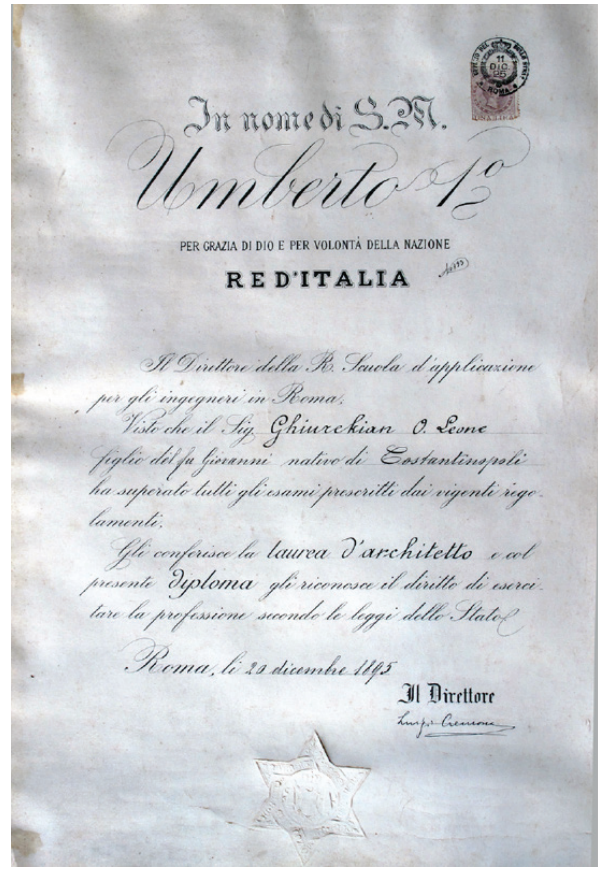

G. 5: Levon Güreğyan'nın Roma Kraliyet Mühendislik Uygulama Okulu (Regia Scuola di Applicazione per gli Ingegneri) diplomas1 (http://www.gurekian.com/index.html ) 
Bebek Hilmi Bey Yalısı (1899), Nişantaşı Sadrazam Halil Rıfat Paşa Konağı (1899), Sami Paşa Köşkü (1900), Giritli Mustafa Paşa Karakolu, Büyükada Mustafa Bey Köşkü (1900), Büyükada Agopyan Köşkü (1903), günümüzde Gümüşsuyu Palas olarak tanınan Hovsep Azaryan Apartmanı (1903), Şişli Şahbaz Makbud Apartmanı (1905) Güreğyan'ın İstanbul içinde ve Adalar'da tasarladığı yapılara örnek oluşturmaktadır. $^{63}$

Levon Güreğyan 1901 yılında, Osmanlı iş adamı ve 1901 yılından itibaren İstanbul Ticaret Odası'nın başkanlığını da yapmış olan Bedros Azaryan'ın kızı Maryamig Azaryan (1875-1956) ile evlenmiştir. ${ }^{64} 1902$ y1lında çiftin tek çocukları olan Ohannes doğmuştur. ${ }^{65}$ Güreğyan'ın Azaryan ailesi, Osmanlı devletine kuşaklar boyu mimarlık hizmeti veren Balyan ailesi ${ }^{66}$ ve Ermeni Katolik cemaati ${ }^{67}$ ile olan yakın ilişkileri ona mesleki anlamda önemli katkılar sağlamıştır. Kısa bir süre kaldığı İstanbul'daki yoğun mimari üretimi ve İtalya'ya döndükten sonra Osmanlı hükümeti adına yaptığı çalışmaları bu ilişkilerin bir sonucu olmalıdır.

Levon, çekirdek ailesiyle birlikte 1907 yılında yeniden Roma'ya taşınmıştır. İtalya'ya döndükten sonra Osmanlı hükümeti ile iş bağlantılarını sürdürmüştür. 1911 yılında Torino Uluslararası Sergisi için Osmanlı pavyonunu tasarlamış ve uygulamıştır. Aynı yılın Eylül ayında, Osmanlı hükümeti tarafından, Roma’da düzenlenen Uluslararası Mimarlar Kongresi'ne temsilci olarak atanmıştır. Ancak Osmanlı ve İtalya arasında başlayan Trablusgarp Savaşı nedeniyle Levon bu kongreye bireysel bağlantılarıyla katılmıştır. Amcasının da içinde olduğu, Ermeni cemaatinin Venedik'teki varlığı Levon'u Treviso'nun Asolo kasabasına yerleşmeye yöneltmiştir. Burada, 1924 yılında, Ağrı Dağı'ndan ilham alarak tasarladığı "Villa Ararat" isimli aile evini inşa etmiştir. Levon Güreğyan, 1910-1913 yılları arasında Ravenna, Aquileia, Istria, Dalmaçya, Brianza gibi merkezlere bazı geziler düzenleyerek buralardaki Bizans ve Ro-

63 Güreğyan’ın mimari etkinlikleri üzerine kapsamlı bilgi için Gurekian, Léon Gurekian Architetto. Ayrıca bk. Alyson Wharton, "Armenian Architects And 'Other' Revivalism," Revival: Memories, Identities, Utopias, ed. Ayla Lepine, Matt Lodder ve Rosalind McKever (London: The Courtauld Institute of Art, 2015), 130-167; Alyson Wharton-Durgaryan, “ 'I Understood that He Is Entrusted to Serve Some Great Business Undertaking': Armenian Architects Reshaping the Ottoman East in the Hamidian Era (1876-1909)," Art, Trade and Culture in the Islamic World and Beyond From the Fatimids to the Mughals, ed. Alison Ohta, J. M. Rogers ve Rosalind Wade Haddon (London: Gingko Library, 2016), 130-131; Oya Şenyurt, "Geç 19. ve Erken 20. Yüzyılda İstanbul’da Etkinlik Göstermiş Bazı Ermeni Mimarlar,” Arredamento Mimarlık 11 (2002), 79.

64 Pamukciyan, Ermeni Kaynaklarından Tarihe Katkılar-IV: Biyografileriyle Ermeniler, 64.

65 Güreğyan ailesinin diğer üyeleri hakkında bilgi için bk. Gurekian’s Home Page, erişim 16 Eylül 2021, http:// www.gurekian.com/index.html .

66 Sarkis Balyan, çok sayıda çizim ve fotoğraftan oluşan kişisel arşivini, aralarında yakın bir dostluk ilişkisi olduğu anlaşılan Levon Güreğyan'a teslim etmiștir. Söz konusu arşiv, Levon'un ölümünden sonra da uzun yıllar ailenin Asolo'daki evinde, Villa Ararat'da korunmuştur. Nihayetinde Balyan arşivi, Levon Güreğyan'ın vasiyeti üzerine, 2014 y1lında torunu Armen Gurekian tarafından Ermenistan Alexander Tamanian Ulusal Mimarlık-Müze-Enstitüsü koleksiyonuna bağışlanmıştır. Bk. Uras, Balyanlar: Osmanlı Mimarllğı ve Balyan Arşivi, 26-30; Gurekian, Léon Gurekian Architetto, 5-6.

67 Örneğin Levon'un amcası Venedik Mıkhitarist cemaatinin başrahibiydi. Gurekian, Léon Gurekian Architetto, 10. 
manesk anıtlar üzerinde incelemeler ve belgelemeler yapmıştır. Ermeni mimarisinin Romanesk mimari üzerindeki etkilerini araştırmıştır. Bu araştırmalar sırasında tuttuğu notları ve hazırladığg çizimleri defterler hâlinde kaydetmiştir. ${ }^{68}$

Güreğyan 1921 yılında İstanbul'u son kez ziyaret etmiş ve ardından tekrar Asolo’ya dönmüştür. 1926 yılında ise İtalyan vatandaşı olmuştur. Bu dönemlerde mimariyi tamamen bırakarak Asolo’daki çiftliğiyle ve fotoğrafçılıkla ilgilenmiştir. Araştırmacı ve yazar kimliğiyle, çoğunlukla Ermenice olmak üzere, bir dizi siyasi yazı ve filolojik makale yayınlamıştır. II. Dünya Savaşı sonunda, Ermeni Sovyet Sosyalist Cumhuriyeti'nden bir heyet tarafından Ermenistan'a taşınması için davet edilmiş ancak Güreğyan bu teklifi reddetmiştir. 2 Eylül 1950'de Asolo'da hayata veda etmiştir.69

\section{Torino Uluslararası Endüstri ve Çalışma Sergisi'ndeki Osmanlı Pavyonu}

Levon Güreğyan’ın 1911 Torino sergisi için Osmanlı pavyonu tasarımı görevini almasında, yeteneğini ve üretkenliğini İstanbul'da yaptığı yapılarla kanıtlaması ve İtalya' da yaşaması etkin rol oynamış olmalıdır. Osmanlı'nın mimari geçmişini tanıyan biri olması da tercih sebebi sayılabilir. Bunun yanında, dönemin İttihat ve Terakki kabinesinde Ermeni bakanların varlığının bu görevi almasını kolaylaştırdığı açıktır. Torino sergisine Osmanlı katılımının İstanbul'daki organizasyonu, Ticaret ve Nâfia Nezareti bünyesinde yapılmıştır. Sergi hazırlıklarının yapıldığı dönemde, Ticaret ve Nâfia Nazırı Bedros Hallacyan'dır. ${ }^{70}$ Sergi tasarımı ve uygulaması için Hallacyan'ın kendi cemaatinden bir mimar olan ve İtalya' da yaşayan Güreğyan ile bağlantıyı sağlama ihtimali kuvvetlidir.

Osmanlı Arşivi’nde bulunan, sergi komiseri Ali Rıza Bey’in hazırladığg yazı ekindeki Osmanlı pavyonunun planı "Prof. Léon Gurekian Architecte Ingenieur" ibaresinin bulunduğu kaşe ile mimarın imzasını taşımaktadır ${ }^{71}$ (G. 6). Mimarın adı ve unvanı, planın bir köşesine Arap harfleriyle de yazılıdır. Planın üzerinde "Pavillion Ottoman à L'Exposition de Turin 1911" yazısı bulunmaktadır. Pavyon kare planlı bir yapıdır. İç mekânda bölümlerin isimleri ve ölçüleri yazılıdır. Buna göre, yapının ön cephesindeki (façade principale) giriş verandasından sonra ana salona (hall central) ulaşılmaktadır. Girişin tam karşısındaki bölüm onur salonu (salle d'honneur) olarak düzenlenmiştir. Yazışmalarda da belirtildiği gibi ${ }^{72}$ bu bölüm resmî kabuller için tasarlanmıştır. Burası yapının arka cephesindeki bir terasa açılmaktadır. Onur salonunun sağında (plana bakış açısına göre) komiser odası (cabinet du commissaire) yer almıştır. Onur salonu-

68 Gurekian, Léon Gurekian Architetto, 9-12, 83.

69 Gurekian, Léon Gurekian Architetto, 11-12.

70 Yervant G. Çark, Türk Devleti Hizmetinde Ermeniler, 1453-1953 (İstanbul: Yeni Matbaa, 1953), 194, 235236; Pamukciyan, Ermeni Kaynaklarindan Tarihe Katklar-IV: Biyografileriyle Ermeniler, 238.

71 BOA, DH.ID. 108/11-7.

72 Başkanlık Osmanlı Arşivi (BOA), Bab-1 Ali Evrak Odası (BEO) 3806/285423-2, H 17 Ramazan 1328/R 8 Eylül 1326 (21 Eylül 1910). 
nun solundaki odadan başlayıp, saatin tersi yönünde olmak üzere, yapının merkezine açılan tüm bölümler A'dan F harfine kadar kodlanmıştır. Bu kodlamalar sergilenecek ürünlerin sınıflandırılmasına yönelik olmalıdır.

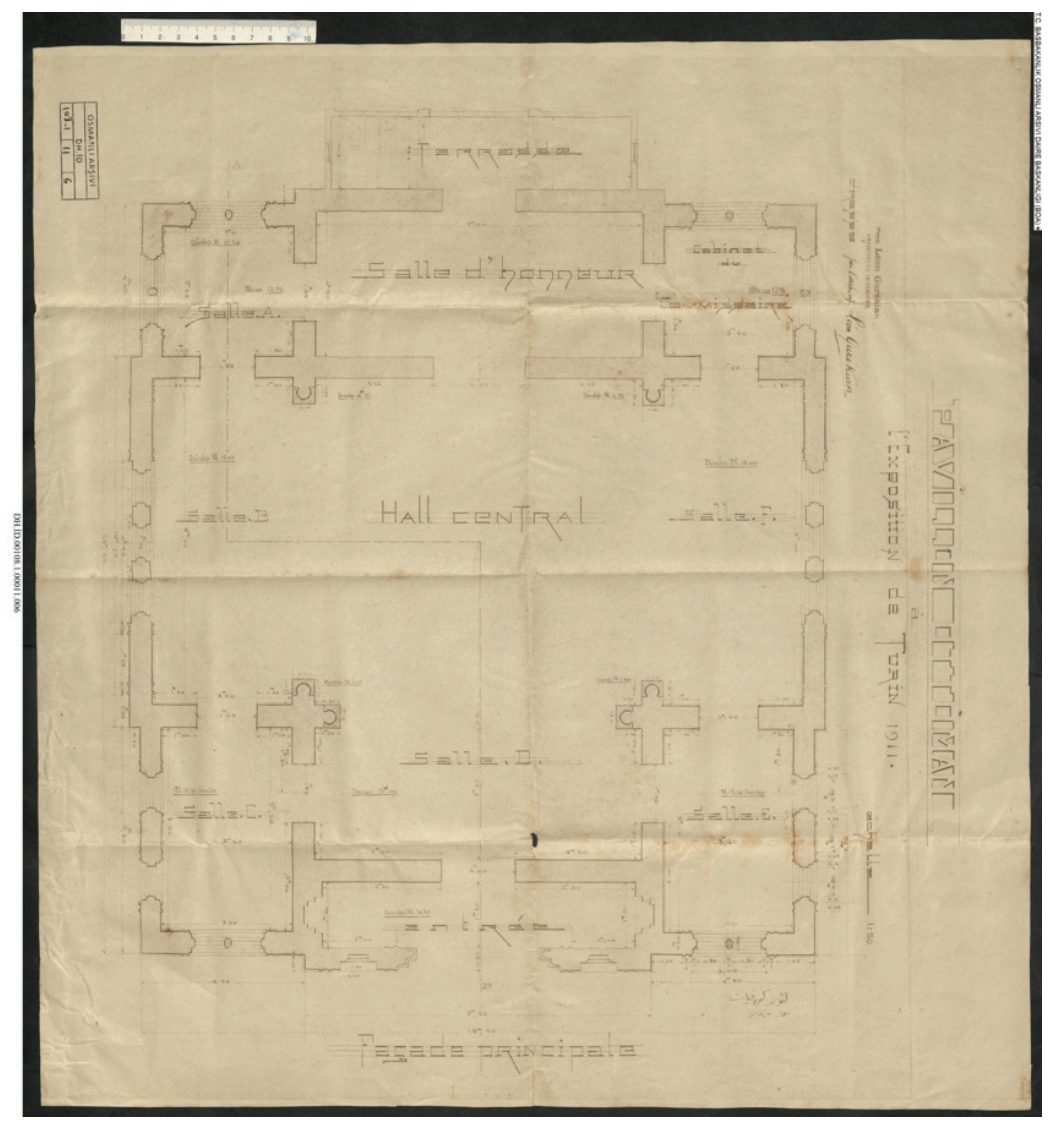

G. 6: 1911 Torino Uluslararası Endüstri ve Çalışma Sergisi'ndeki Osmanlı pavyonunun Levon Güreğyan imzalı planı (BOA, DH.İD.) 108/11)

Osmanlı pavyonunun giriş katına ait olan bu plan özünde merkezi sofalı bir düzeni yansıtmaktadır. Pavyonun bir suluboya perspektif çizimi Armen Güreğyan tarafından yayınlanmıştır ${ }^{73}$ (G. 7). Bu çizimden ve yapıya ait dönem fotoğraflarından ${ }^{74}$ binanın

73 Gurekian, Léon Gurekian Architetto, 79. Bu çalışma kapsamında, Armen Bey’e, Güreğyan ailesinin Asolo’daki arşivinde, 1911 Torino sergisindeki Osmanlı pavyonuyla ilgili farklı çizimlerin olup olmadığı konusunda ulaşılmaya çalışılmıştır. Ancak 2020 ve 2021 yıllarında Covid 19 pandemi koşulları nedeniyle bu çabalar sonuçsuz kalmıştır. Söz konusu sergiye ait farklı çizimlere daha sonraki süreçte ulaşılması hâlinde, bu çalışmayı tamamlar nitelikte yeni bir değerlendirme yapılabilir.

74 Osmanlı pavyonuna ait dönem fotoğrafları sergiyle ilgili Torino'da basılan rehber kitapçıklar ve sergi kapsamında yapılan süreli yayınların çoğunda bulunmaktadır. Bk. Guida Ufficiale della Esposizione Internazionale: Torino 1911, 133. Osmanlı pavyonunun fotoğrafları İstanbul basınında da yer almıştır. Şehbal dergisi 14 Mayıs 1911 tarihli sayısında "Güreğyan Efendi" ve tasarladığı Osmanlı pavyonunun fotoğraflarını yayımlamıştır. Şehbal 39, R 1 Mayıs 1327 (14 Mayıs 1911), 297. Ayrıca dönem kartpostallarında da bu binanın fotoğraflarına rastlanmaktadır. Bk. Salt Araştırma, Fotoğraf ve Kartpostal Arşivi, Katalog Numara: AHTOR001. 
cephe özelliklerini ve üslubunu analiz etmek mümkündür (G. 8, G. 9, G. 10). Çizime ve fotoğraflara göre, pavyon iki katlı bir köşk biçiminde tasarlanmıştır. Ön cephesinde, merdivenlerle ulaşılan sivri kemerli bir giriş bulunmaktadır. Girişin iki yanında, kemer başlangıcı seviyesinde, yine sivri kemerli nişler ve ikiz pencereler yer almaktadır. Geniş bir saçağa sahip olan yüzölçümü daha küçük ikinci kat ise, üçlü kemer düzenlemesiyle dışarı açılmaktadır. Öne doğru çıkan bu bölümün diğer cephelerinde, yine sivri kemerli ikiz pencereler kullanılmışıı. Pencere düzenleri yapının arka cephesinde de tekrarlanmaktadır (G. 10). Ancak burada, ön cephedeki anıtsal girişin yerini dışa taşkın teras bölümü almıştır. Süsleme ön cepheye göre daha sadedir. Hem ön hem de arka cephede, giriş kat seviyesindeki pencereler üzerine süsleme kartuşları görülmektedir. Ancak yapının döneme ait fotoğraflarından ve Armen Güreğyan'ın yayımladığı perspektif çiziminden, kartuşlardaki süslemelerin detayları seçilememektedir.

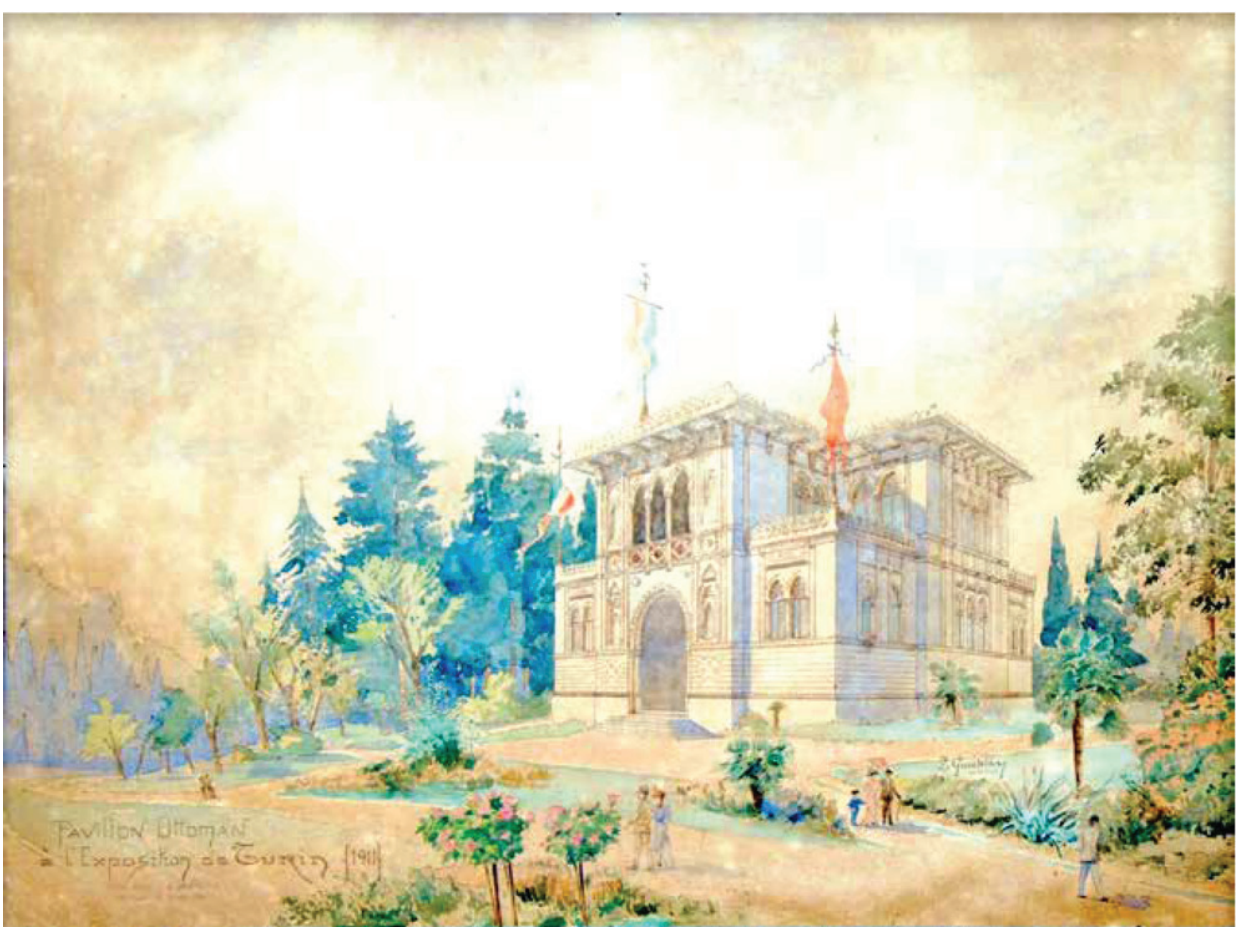

G. 7: 1911 Torino Uluslararası Endüstri ve Çalışma Sergisi için Osmanlı Pavyonu, perspektif çizimi, 57x43 cm. (Armen Gurekian, Léon Gurekian Architetto, 79) 


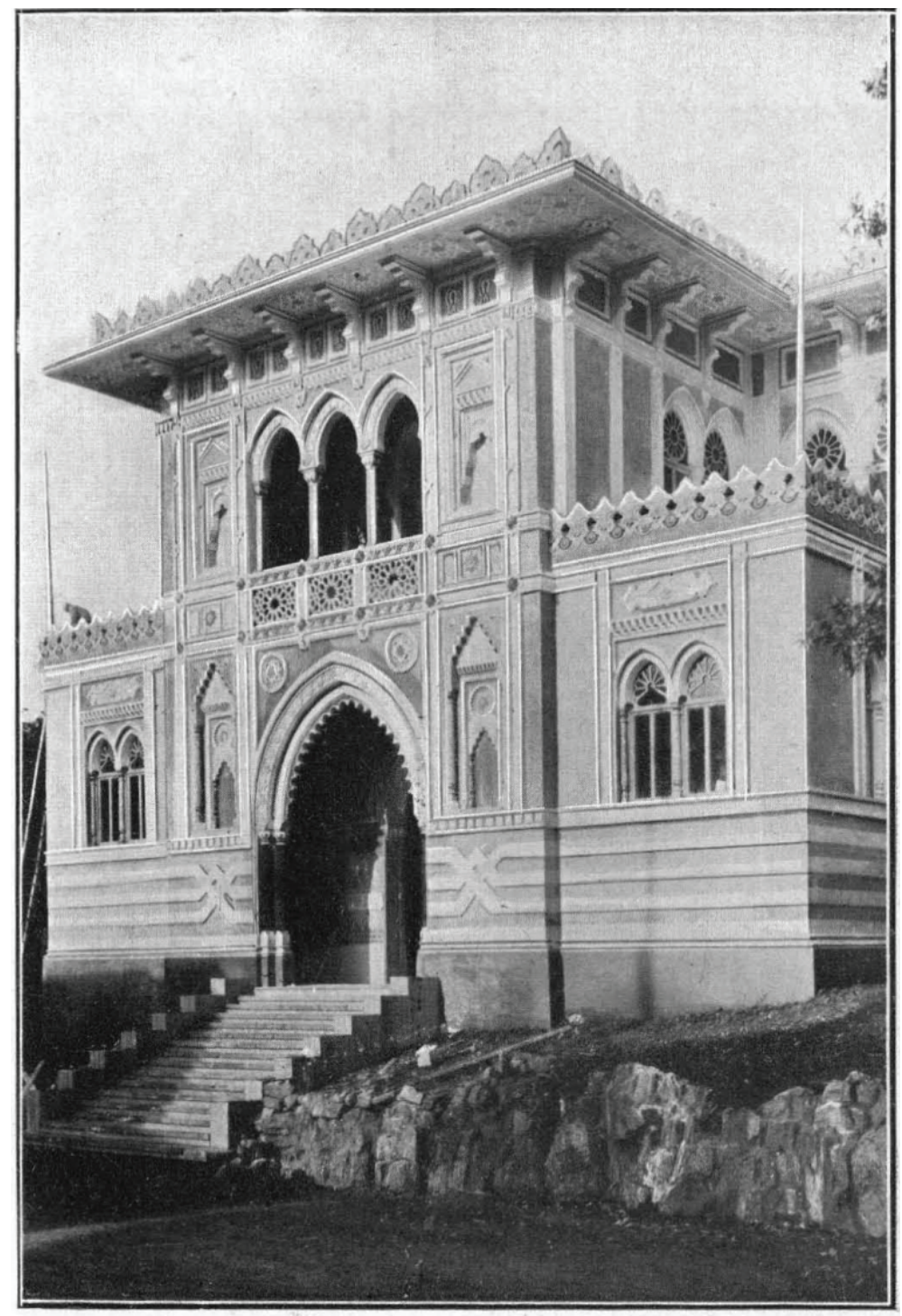

G. 8: 1911 Torino Uluslararası Endüstri ve Çalışma Sergisi için Osmanlı Pavyonu (Guida Ufficiale della Esposizione Internazionale: Torino 1911,133) 


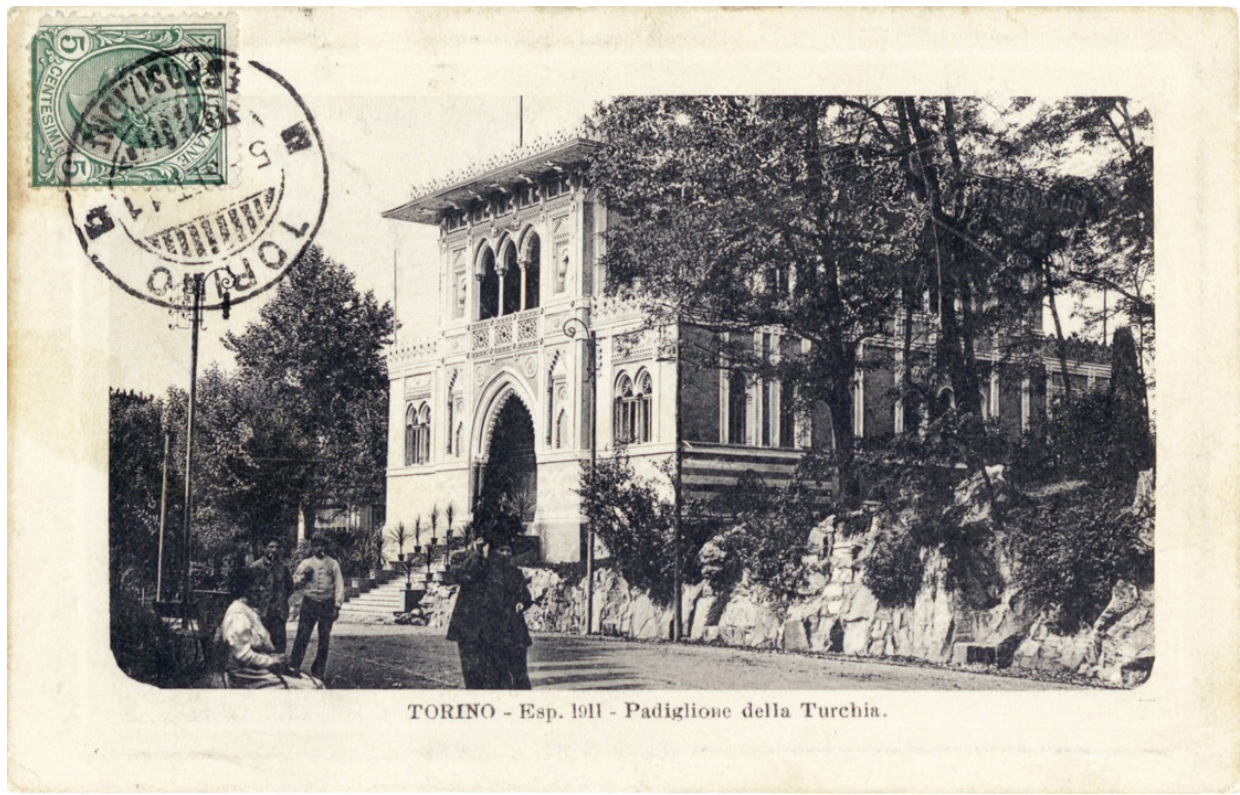

G. 9: 1911 Torino Uluslararası Endüstri ve Çalışma Sergisi için Osmanlı Pavyonu

(Salt Araştırma, AHTOR001)

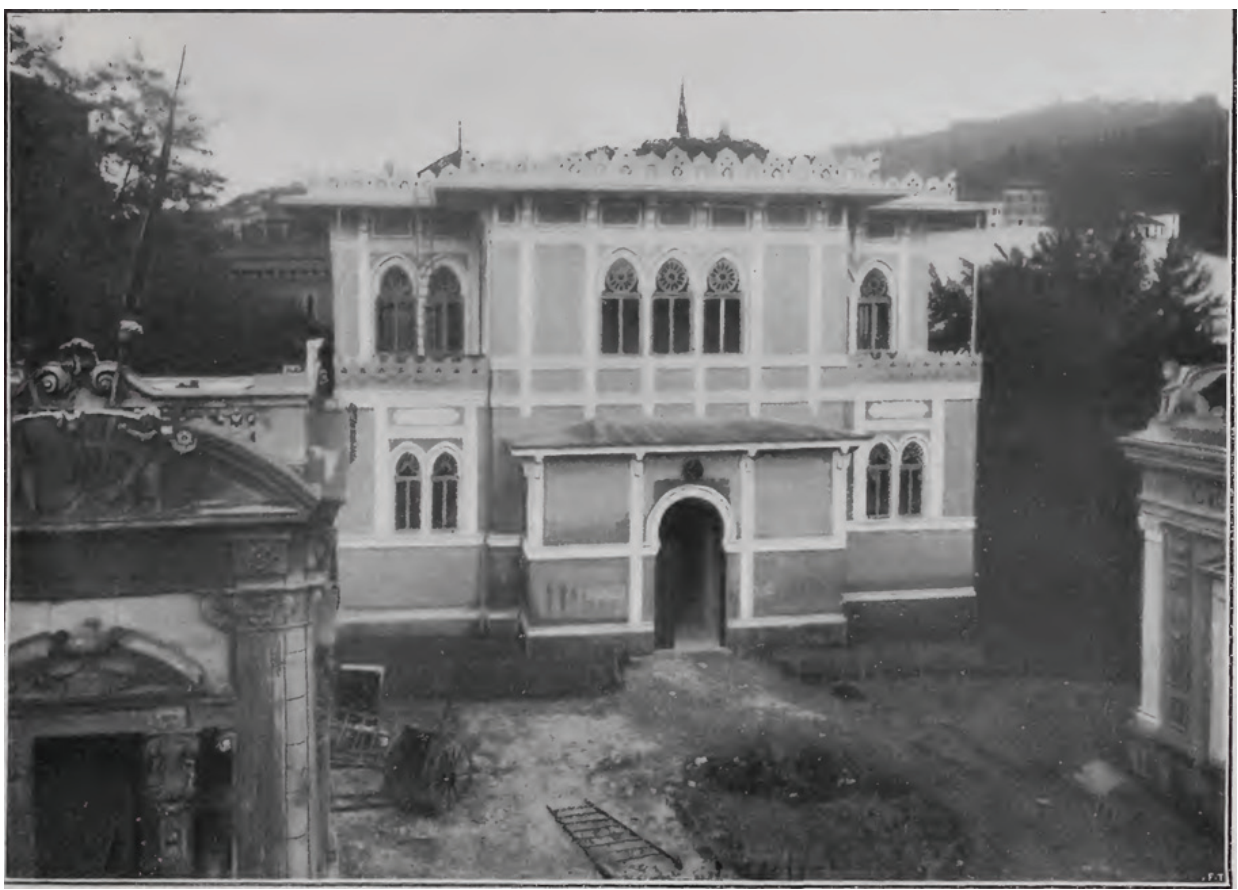

G. 10: 1911 Torino Uluslararası Endüstri ve Çalışma Sergisi için Osmanlı Pavyonu, arka cephe (Le Esposizioni del 1911: Torino, Roma, Firenze, 204) 
Pavyon genel hatlarıyla, Dünya sergilerindeki Osmanlı temsillerinde alışılmış olduğu üzere, Oryantalist beğeni ile Osmanlı biçimlerini birleştiren bir yapıdır. $\mathrm{Bu}$ anlamda, kısmen de olsa, plan ve üslup olarak Seyfeddin Bey’in Roma sergisi için önerdiği “milli mimari” fikriyle uyuşmaktadır. Güreğyan’ın, bu öneriyi dikkate alarak oluşturduğu tasarımda Yeşil Cami’den ne kadar ilham aldığı, şu ana kadar ulaşılan verilere göre bilinmemektedir. Bununla birlikte, iki yapı arasında bazı ilişkiler kurulabilir. Güreğyan tasarımında merkezi sofalı planı tercih etmesi üzerinde Yeşil Cami’nin “ters T planlı" kurgusunun etkili olup olmadığı sorgulanabilir. Bilindiği gibi, zaviyecami işlevli bu tür planlar eyvan-sofa düzenine dayanmaktadır. Güreğyan, Seyfeddin Bey'in önerisinden yola çıkarak, bu planı sadeleştirerek pavyona uygulamış olabilir. Ancak, aynı döneme ait Çinili Köşk gibi merkezi sofalı konut yapılarından ilham almış olması daha gerçekçi gözükmektedir. Nitekim pavyon diş kütle itibariyle daha çok bir Osmanlı köşkü biçimdedir. Giriş cephesinde, iki katta da düzenlenmiş olan sivri kemerli mihrap nişleri, Yeşil Cami’nin giriş cephesindeki nişleri hatırlatmaktadır. Yeşil Cami için bir son cemaat yeri revakı tasarlandığı ancak bunun yapılmadığı kabul edilmektedir. ${ }^{75}$ Cephede giriş seviyesindeki mihrap nişlerinin varlı̆̆ son cemaat yerine işaret eden izlerdendir. Güreğyan'ın tasarımında kullandığg Yeşil Cami benzeri mihrap nişleri, daha yüzeysel olup süsleme amaçlıdır. Benzer yüzeysel mihrap nişleri Pertevniyal Valide Sultan Camii'nin (1871) cephesinde de vardir.

Güreğyan'ın tasarımındaki ilham kaynağının Yeşil Cami’nin başta geldiği, erken Osmanlı yapılarının biçim dağarcığından beslenen İstanbul'daki Oryantalist mimarinin öncü yapıları olduğu daha açıktır. Nitekim Güreğyan'ın yapısının üslubu bir bütün olarak değerlendirildiğinde, Oryantalist ögelerin ağırlık kazandığı görülmektedir. Örneğin, âdeta bir taç kapı gibi tasarlanan giriş kemerinin iç yüzeyi, Magrip-Endülüs mimarlığında karakteristik olan dilimlerle hareketlendirilmiştir. ${ }^{76}$ Benzer şekilde, stilize palmet motiflerinden oluşan saçak kornişleri Oryantalist mimarinin ruhunu yansıtmaktadır. Şebekeleriyle birlikte hafif sivri kemerli pencereler, yapıya Gotik bir ifade katmaktadır. Osmanlı üslubundan farklı düzenlenmiş geometrik motifli korkuluklar Oryantalist etkiyi arttırmaktadır. Saçak altında görülen niş dizileri, alışılmadık konumlarıyla, Pertevniyal Valide Sultan Camii ve Çırağan Sarayı (1871) başta olmak üzere, İstanbul'daki birçok Oryantalist yapıda görülmektedir. ${ }^{77}$ Pencere üstlerindeki kartuşlar için de aynı benzerlik kurulabilir. Dönem anlatılarından ${ }^{78}$ ve bazı kartpos-

75 Ekrem Hakkı Ayverdi ve İbrahim Aydın Yüksel, İlk 250 Senenin Osmanlı Mimarisi (İstanbul: İstanbul Fatih Cemiyeti, 1976), 50; Doğan Kuban, Osmanlı Mimarisi (İstanbul: YEM Yayın, 2007), 98.

76 Osmanlı mimarlığında kullanılan bu tür kemerler için bk. Turgut Saner, 19. Yüzyıl İstanbul Mimarlı̆̆ında “Oryantalizm” (İstanbul: Pera Turizm ve Ticaret, 1998), 40-42.

77 Niş dizilerinin kullanıldı̆̆ı diğer Oryantalist yapılar ve bunların Magrip-Endülüs referansları için Saner, 19. Yüzyll İstanbul Mimarlığında “Oryantalizm”, 42-44, 63-66.

78 Guida Pratica della Esposizione Internazionale di Torino, 1911, 49. Bu yayında Osmanlı binası için “... pembe, görkemli bir cephesi ve kemerli girişi olan bir pavyon.” ifadesi kullanılmıştır. La Guida Tricolore Rimborsabile di Torino e della Esposizione del 1911 (Milano: F. De Rio, 1911), 132; L'Esposizione di Torino: Giornale Ufficiale Illustrato dell'Esposizione Internazionale delle Industrie e del Lavoro 1911, 25 (Torino: Stabilimento Tipografico Momo, 1911), 390. Bu iki yayında da binanın "çok renkli" dekorasyonunun etkisinden bahsedilmektedir. 
tallardan anlaşıldığına göre, dış cephede yine Oryantalist mimariye referans verecek biçimde, renk unsuru olarak pembe malzeme kullanılmıştır. Türü tespit edilemeyen bu malzeme kemer ve kartuş dolgularında görülmektedir. Daha açı renkli bir pembe malzeme ile subasman katında iki renkli taş izlenimi yaratılmış, böylece egzotik etki arttırılmıştır.

Bu çalışma kapsamında yapının iç dekorasyonuna ait görsel bir belgeye ulaşılamamıştır. Bu nedenle, Seyfeddin Bey’in yazısında önerdiği gibi, çinilerle süslü olup olmadığı anlaşılamamıştır. Öte yandan, Kevork Pamukciyan, Güreğyan'ın bu yapıyı tasarlarken 1910 yılında yanan Çırağan Sarayı'nın resimlerinden yararlandığını belirtmektedir. ${ }^{79}$ Özellikle, iç mekânın tavan dekorasyonunda bu saraydan doğrudan alıntı yaptığını aktarmaktadır. Eğer bu bilgi doğru ise Güreğyan'ın iç mekân tasarımında Çırağan'ın taht salonu gibi çok renkli bir atmosfer hâkim olmalıydı.

Bütün bu özellikleriyle Güreğyan'ın tasarladığı sergi binasının 1867 Paris sergisinden beri yerleşen, Osmanlıların Batı'ya karşı mimari temsil geleneğini sürdüren bir yaklaşıma sahip olduğu söylenebilir. Bu bağlamda, Osmanlı ve Osmanlı dışı İslami ögeleri birleştiren, Batılıların egzotik zevklerini de karşılayan bir yapı olarak dikkat çekmektedir. Burada, bu geleneğin düşünsel altyapısını oluşturan kaynaklara değinmek yararlı olacaktır. Öncelikle, Yeşil Cami'nin neden odak noktası haline geldiğinin üzerinde durmak gerekmektedir. Yeşil Cami 1867 Paris sergisinde de Osmanlı kimliğini temsil eden yapıların iham kaynakları arasındaydı. Léon Parvillée tarafindan, Giovanni Battista Barborini iş birliğiyle bu sergi için hazırlanan cami, hamam, köşk ve çeşmeden oluşan yapı grubu, Osmanlı'nın erken dönem yapılarından esinlenmişti. ${ }^{80}$ Yap1 grubundan cami bölümü, plan bakımından olmasa da süslemeleri ile Yeşil Cami’ye, Boğaziçi Köşkü ise Çinili Köşk’e referans vermekteydi. ${ }^{81}$ Parvillée, 18631867 yılları arasında, Osmanlı Devleti tarafından Bursa'nın 14. ve 15. yüzyıl yapılarının restorasyonu için görevlendirilmişti. Bu deneyimin üzerine, 1867 Paris sergisinin Osmanlı komisyonu, tasarımı yapacak olan mimarlardan İstanbul ve Bursa'nın tarihî anıtlarını referans almalarını istemişti. ${ }^{82}$

Osmanlıların kuruluşundan sonuna kadar ürettiği sayısız eser içinde, özellikle en olgun kabul edilen 16. yüzyıl anıtları dururken, bu tür sergilerde Bursa Yeşil Cami'nin veya diğer erken dönem anıtlarının model olarak seçilme nedenlerinin kökleri geç Tanzimat ideolojisinin modern bir mimari kimlik oluşturma çabalarında aranmalıdır. Geç dönem Osmanlı aydınları Tanzimat'ın eşitlikçi ve kapsayıcı hanedan vizyonunun

79 Bu bilgi, Pamukciyan'ın Uğur Tanyeli’ye 5 Mayıs 1993 tarihinde verdiği Levon Güreğyan biyografisinin yazılı olduğu bir nota dayanmaktadır. Bk. Uğur Tanyeli, Mimarlığın Aktörleri Türkiye, 1900-2000 (İstanbul: Garanti Galeri, 2007), 383.

80 Çelik, Şarkın Sergilenişi 19. Yüzyll Dünya Fuarlarında İslam Mimarisi, 102-111.

81 Yazıc1, "Uluslararası Sergilerde Osmanlı Mimarisi'nin Sunumu," 24.

82 Ahmet Ersoy, Architecture and the Late Ottoman Historical Imaginary: Reconfiguring the Architectural Past in a Modernizing Empire (Burlington: Ashgate, 2015), 52. 
oluşumunda erken dönemin çok kültürlü yapısıyla ilişki kurmuştur. Dönemin tarih yazımında, özellikle I. Mehmed (Çelebi Sultan Mehmed) dönemine, tam anlamıyla bir canlanma ve ilerleme çağı olarak bakılmıştır. ${ }^{83} \mathrm{Bu}$ düşünce I. Mehmed döneminde, Ankara Savaşı yenilgisinden sonra, Osmanlı Devleti’nin Anadolu ve Balkanlar'da yeniden hâkim bir güç olarak ortaya çıkması temeline dayanmaktadır. Bu başarı, eski siyasi ve ekonomik gücünü kaybetmiş Osmanlı yönetimini ayağa kaldırmak için çabalayan Tanzimat reformcularına ilham vermiş olmalıdır. 1860'larda Abdülaziz döneminde başlayıp II. Abdülhamid döneminde geniş ölçüde devam eden, Bursa ve çevresindeki erken dönem anıtlarına odaklanan restorasyon ve yeniden inşa faaliyetleri bu anlayışın mimarlık alanına yansımasıdır. ${ }^{84}$ Parvillée de bu kapsamda görev almıştır.

Tanzimat sonrası dönemde bu faaliyetlere paralel olarak Osmanlı mimarlık tarihine odaklanan öncü bilimsel yayınlar yapılmıştır. Usul-i Mimari-i Osmani adlı kitap bu anlamda önemli bir yere sahiptir. ${ }^{85} 1873$ 'te Viyana Uluslararası Sergisi için hazırlanan, Osmanlı mimarlık tarihinin milli bir kurguyla, kronolojik bir sırayla ele alındığ bu çalışmada, erken dönem Osmanlı anıtları ilgi odağı haline getirilmiştir. Kitapta oldukça geniş bir yer ayrılan Yeşil Cami'den Osmanlı mimari usullerinin en yüksek düzeyde uygulandığı yapı olarak bahsedilmiştir. Kitabın yazarlarına göre, Yeşil Cami, plan açısından pek erdemli olmasa da dengeli, uyumlu, görkemli dekorasyonu ile eşsiz bir yere sahiptir. ${ }^{86}$ Usul-i Mimari'de Osmanlı mimarlık tarihi içinde vurgulanan bir başka dönem, kitabın hazırlandığı Abdülaziz dönemidir. Kitapta onun saltanatında inşa edilen Pertevniyal Valide Sultan Camii ve Çırağan Sarayı Osmanlı mimarisinin gelişkin örnekleri olarak gösterilir. 18. yüzyıl ortalarından itibaren Osmanlı mimarisinde görülen Batı etkilerinin eleştirildiği çalışmada, Abdülaziz döneminden yeni bir canlanma dönemi olarak bahsedilir. ${ }^{87}$

Bu dönemde hazırlanan bir diğer yayın Parvillée'nin Architecture et Décoration Turques au XVe siècle (Paris, 1874) adlı kitabıdır. Parvillée bu çalışmasında, Bursa'daki restorasyon tecrübelerinin etkisiyle, doğrudan erken Osmanlı dönemi mimarisine, özellikle dekorasyonuna odaklanmaktadır. Usul-i Mimari'nin yazarları gibi, Parvillée de çalışmasında erken dönem Osmanlı sanatının benzersiz bir sentez olduğunu vurgulamıştır. Çalışmasında Yeşil Cami ve Yeşil Türbe’ye ayrıcalıklı bir yer

$83 \mathrm{Bu}$ konu Ahmet Ersoy tarafından etraflıca tartışılmıştır. Bk. Ahmet Ersoy, "Architecture and the Search for Ottoman Origins in the Tanzimat Period," Muqarnas 24 (2007), 117-139; Ersoy, Architecture and the Late Ottoman Historical Imaginary: Reconfiguring the Architectural Past in a Modernizing Empire.

84 Ersoy, "Architecture and the Search for Ottoman Origins in the Tanzimat Period," 130.

85 Edhem Pacha, Usul-i Mimari-i Osmani/ L'Architecture Ottomane /Die Ottomanische Baukunst (Isstanbul, 1873). Bu yayının ve tarihsel bağlamının kapsamlı değerlendirmesi için Ersoy, Architecture and the Late Ottoman Historical Imaginary: Reconfiguring the Architectural Past in a Modernizing Empire.

86 Edhem Pacha, Usul-i Mimari-i Osmani/L'Architecture Ottomane /Die Ottomanische Baukunst, 22-26; Ersoy, "Architecture and the Search for Ottoman Origins in the Tanzimat Period," 126-128.

87 Nurcan Yazıcı, “Osmanlı’nın İlk Mimarlık Kitabı: Usul-u Mimari-i Osmani,” Arkitekt 497 (2003), 17-18. 
ayırmıştır. ${ }^{88}$ Parvillée bu kitabı yazmadan önce, 1863 'te Sultanahmet'te düzenlenen, cephesinde Çinili Köşk’ten esinler taşıyan, Sergi-i Umumi-i Osmani binasının iç dekorasyonunu da gerçekleştirmiştir. ${ }^{89}$

Bütün bu girişimlerle eş zamanlı olarak, 19. yüzyılın ikinci yarısından itibaren Osmanlı mimarisinde kimlik arayışları ifadesini Oryantalist üslupta bulmuştur. ${ }^{90}$ Osmanlı mimarisinde kullanılan Oryantalizm, ağırlıklı olarak erken dönem Osmanlı ve Magrip-Endülüs kaynaklı mimari formları birleştiren, bazen de Gotik biçimleri içine alan eklektik bir üsluptur. Strüktür yerine, cephe ve dekorasyonun öncelikli olduğu bu üslup, Abdülaziz döneminden II. Abdülhamid dönemi sonlarına kadar, başkentteki bazı simge yapılar ile uluslararası sergilerdeki Osmanlı temsil binalarında kullanılmıştır. ${ }^{91}$

II. Meşrutiyet'in ilanından sonra Osmanl1-İslam sentezine dayalı milliyetçilik yerini, ulus bilincine dayalı bir anlayışa bırakmıştır. Bu dönemde Selçuklu ve klasik Osmanlı mimarlık repertuvarından alınan ögelerle şekillenen bir canlandırmacılık gündeme gelmiştir. Böylece, döneminde "Milli Mimari Rönesansı" olarak anılan, 1970'lerden itibaren mimarlık tarihçilerinin "Birinci Ulusal Mimarlık Akımı" olarak adlandırdığı anlayış, II. Meşrutiyet döneminden Cumhuriyet'in ilk yıllarına kadar Türkiye mimarlı̆̆ına hakim olmuştur. ${ }^{92}$ Sibel Bozdoğan, Birinci Ulusal Mimarlık Akımı'nın temellerini Usul-i Mimari-i Osmani'nin yazıldığı dönemin ideolojisi ile ilişkilendirmektedir. ${ }^{93}$ Söz konusu kitabın yazarları "milli mimari” kavramını gündeme getirerek daha somut anlamda bir Osmanlı canlandırmacılığının yolunu açmıştır. Bu kez "İslam” değil "Türklük" bilinciyle "yeni bir mimari” oluşturulmaya çalış1miştır.

Osmanlı mimarisinde Ulusal Mimarlık Akımı'nın egemen olduğu bir dönemde, Levon Güreğyan'ın tasarladığı yapı geç Tanzimat beğenisine uygun olarak yapılmıştır. Bu anlamda yapı, erken Osmanlı formlarının Magrip-Endülüs kaynaklı Oryantalist ögelerle kaynaştırılarak sunulduğu mimari anlayışın II. Meşrutiyet Dönemi'nde de kabul gördüğünü kanıtlamaktadır. Başkentteki yapılarda artık tercih edilmese de

88 Ersoy, "Architecture and the Search for Ottoman Origins in the Tanzimat Period," 131; Kitapta yer alan 50 çizimden 28'i Yeşil Cami’ye, 13’ü Yeşil Türbe’ye aittir. Bk. Miyuki Aoki, "Léon Parvillée: Osmanlı Modernleşmesinin Eşiğinde Bir Fransız Sanatçı,” (Doktora Tezi, İstanbul Teknik Üniversitesi, 2002), 142.

89 Bu sergi hakkında kapsamlı olarak bk. Rıfat Önsoy, “Osmanlı İmparatorluğu’nun Katıldığı İlk Uluslararası Sergiler ve Sergi-i Umumi-i Osmani (1863 İstanbul Sergisi),” Belleten 185 (1984), 195-235; Nurcan Yazıc1, “Atmeydanı'nda İlk Osmanlı Sergi Binası ve Mimar Bourgeois-Parvillée-Montani İşbirliği,” Hipodrom/ Atmeydanı: Ístanbul'un Tarih Sahnesi, ed. Ekrem Işın (İstanbul: Pera Müzesi Yayınları, 2010), 128-151.

90 Oya Şenyurt, Osmanlı mimarlığında kullanılan Oryantalist üslubu "Osmanlılık" ve "Panislamizm" siyasetini benimseyen devletin "oksidentalist" tavrının mimariye yansıması olarak değerlendirmektedir. Bk. Oya Şenyurt, "II. Abdülhamid Döneminde Panislamist Siyasetin Mimaride Oksidentalist Temsiliyete Dönüşmesi Üzerine Bir Deneme,” Munzur Üniversitesi Sosyal Bilimler Dergisi 8/15 (2019), 9-32.

91 Bu konuda bk. Saner, 19. Yüzyll İstanbul Mimarlı̆̆ında “Oryantalizm”.

92 Doğan Hasol, 20. Yüzyll Türkiye Mimarlı̆̆ı (İstanbul: YEM Yayınları, 2017), 34.

93 Sibel Bozdoğan, Modernizm ve Ulusun İşası: Erken Cumhuriyet Türkiyesi’nde Mimari Kültür (İstanbul: Metis Yayınları, 2002), 36. 
Batılıların egzotik beklentilerine yönelik olarak, bu üslubun uluslararası sergilerde geçerliliğini koruduğu anlaşılmaktadır. Torino sergisi için hazırlanan dönem yayınlarında yer alan Osmanlı sergi binası ve burada sergilenen eserlerle ilgili yorumlar da bu beklentinin karşılandığını göstermektedir. Sergi için hazırlanan bir rehber kitapta Osmanlı pavyonu "Oryantal” üslubu ve zarif bir etki yaratan ikiz pencereleri ile Osmanlı haremine benzetilmiştir. ${ }^{44}$ Bir başka rehberde ise, "Magribi oryantal üslubu ile bu bina nostaljik egzotizm havasıyla Barok üslubun ahenkli tonunu kırıyor"95 ifadesi kullanılmıştır. Yine bu yayınlarından anlaşıldığına göre, Osmanlı binasındaki teşhir de dikkat çekmiştir. Bunlarda ortak ifade olarak tekstil, halı ve seramiklerin göz alıcı başarısından söz edilmiştir. Nitekim sergiye gönderilen Hereke Fabrikası üretimi halılar büyük ödüle layık görülmüştür ${ }^{96}$ (G. 12). Şehbal dergisi de bu sergide bask1 kalitesinden dolayı altın madalya kazanmıştır. ${ }^{97}$

Torino sergisine bir süre komiserlik yapan Roma Büyükelçiliği müsteşarı Seyfeddin Bey'in dekorasyonu ve özellikle çinileriyle ön planda olan "Yeşil Cami gibi muhteşem yapıların” örnek alınması önerisi, Osmanlı yapılarının üslup tercihlerinde, mimarların eğilimleri kadar baniler ve onları yönlendiren elit kesimin de belirleyiciliğini örneklemektedir. ${ }^{98}$ Güreğyan'ın mimari repertuvarındaki yapılar incelendiğinde, Neo-Klasik’ten Art Nouveau'ya uzanan bir üslup çeşitliliği karşımıza çıkmaktadır. Alyson Wharton'un ${ }^{99}$ işaret ettiği gibi, bu çeşitlilikte olasılıkla banilerin tercihleri belirleyici olmuştur. Tarihî üslupları canlandıran yaklaşımıyla Güreğyan'ın Torino pavyonu için önerilen biçim diline yabancı olmadığı açıktır. Agopyan Köşkü örneğinde olduğu gibi, İstanbul ve Adalar'da uyguladığı yapılarda da at nalı kemer, Gotik pencere, soğan kubbe gibi Oryantalist ögeleri sıklıkla kullanmıştır (G. 11).

94 Guida Ufficiale della Esposizione Internazionale: Torino 1911, 130-131.

95 Guida Pratica della Esposizione Internazionale di Torino, 1911, 49. Burada Torino sergisinin genel üslubunda tercih edilen Barok üslup kastedilmektedir.

96 Önder Küçükerman, Anadolu'nun Geleneksel Halı ve Dokuma Sanatı Içinde Hereke Fabrikası: Saray'dan Hereke'ye Giden Yol (İstanbul: Sümerbank Yayınları, 1987), 53, 150-151.

97 Şehbal 77, R 15 Haziran 1329 (28 Haziran 1913), 95.

98 Benzer yönlendirici fikirleri Osmanlı arşiv belgelerinde bulmak mümkündür. Örneğin Raimondo D’Aronco Dersaadet Ziraat ve Sanayi Sergi-i Umumisi’nin ilk tasarımını II. Abdülhamid'e sunduğunda, (Küçük) Said Paşa Sultan'a üslup meselesini ele aldığı bir rapor yazmıştır. Paşa raporunda İtalyan mimarın önerdiği “Avrupai üslup" kavramının açık olmadığını, tesis edilecek serginin ya yalnızca Osmanlı mimari üslubunu ya da "Hint, Arap, Afrika, Endülüs” üsluplarının bir karışımı olarak, yani “fenn-i mimari-i İslami”ye göre yapılmasının daha uygun olacağını dile getirmiştir. Bk. Hatice Adıgüzel, "Bir Tasarımın İzinde: Yeni Bulgular Işı̆̆ında Raimondo D’Aronco'nun İlk İstanbul Projesi Dersaadet Ziraat ve Sanayi Sergi-i Umumisi,” METU Journal of the Faculty of Architecture 36/1 (2019), 173-174. Aynı Paşa bir başka raporunda, Yıldız Hamidiye Camii'nin minberinde, yine bir erken Osmanlı yapısı olan Bursa Ulu Cami'nden ilham alındı̆̆ı hâlde, sonucun ona yeterince benzememesini eleştirmiş ve yapının süslemesi için öneriler sunmuştur. Bk. Ahmet Ersoy, “Aykırı Binanın Saklı Kalfası: Hamidiye Camisi ve Nikolaos Tzelepis (Celebis)," Batılılaşan İstanbul'un Rum Mimarları, ed. Hasan Kuruyazıcı ve Eva Şarlak (İstanbul: Zoğrafyon Lisesi Mezunları Derneği, 2011), 108.

99 Wharton, “Armenian Architects And 'Other' Revivalism,” 161. 


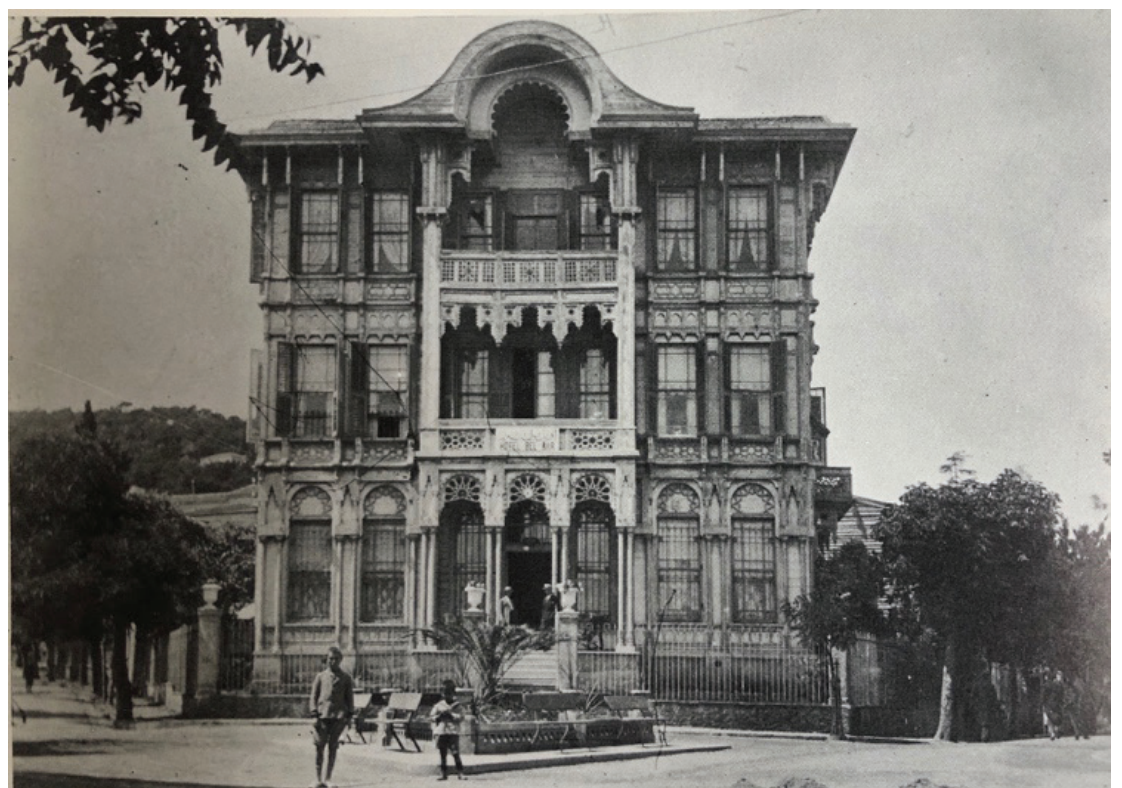

G. 11: Büyükada Agopyan Köşkü, 1903 (Pars Tuğlacı, Tarih Boyunca İstanbul Adaları, 194)

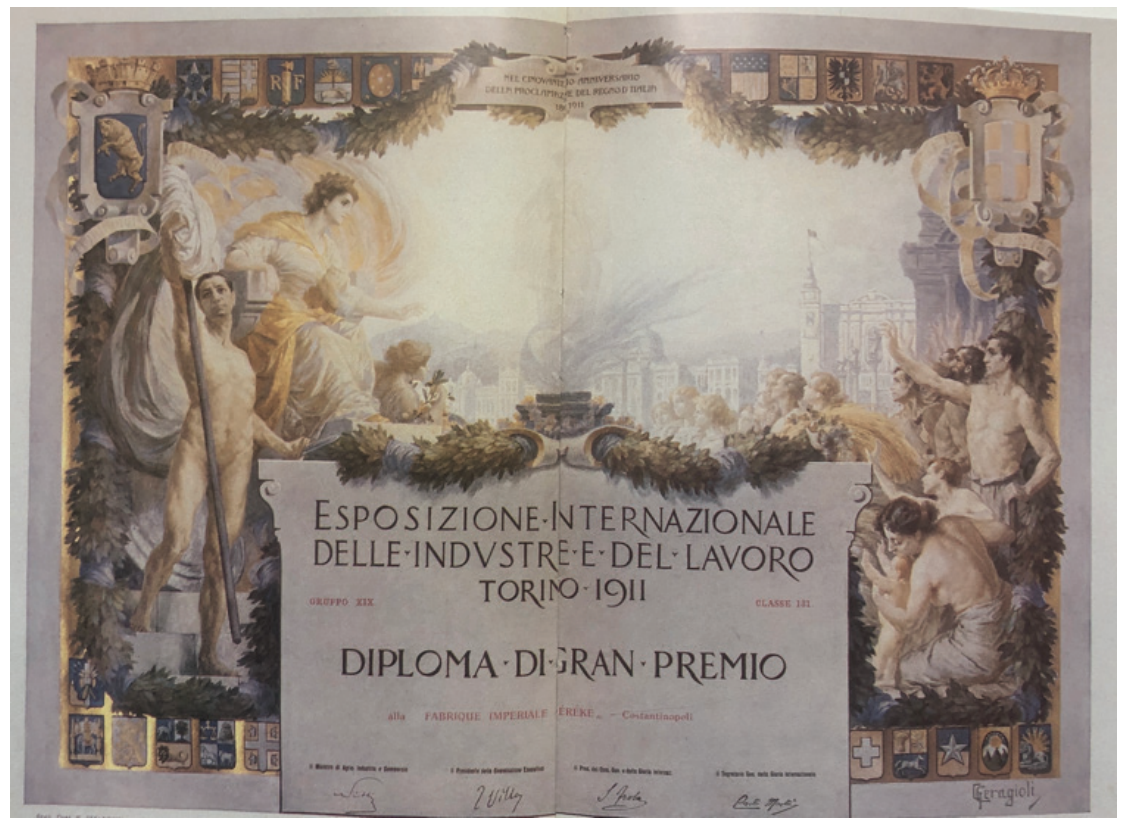

G. 12: Hereke Fabrikası'nın 1911 Torino sergisinde kazandığı büyük ödülün diploması (Önder Küçükerman, Anadolu'nun Geleneksel Halı ve Dokuma Sanatı İçinde Hereke Fabrikası: Saray'dan Hereke'ye Giden Yol, 150-151) 
Torino sergisinin resmi kapanış1 19 Kasım 1911 tarihinde gerçekleşmiştir. Ancak Osmanlı pavyonu ve teşhiri Eylül ayı sonunda başlayan Trablusgarp Savaşı nedeniyle apar topar kapanmak durumunda kalmıştır. Bundan sonraki süreçte Osmanl1-İtalya arasında siyasi bir gerginlik dönemi başlamıştır. Genellikle geçici olarak tasarlanan, Paris Eiffel Kulesi, Grand Palais gibi bazı simge yapılar dışında çoğunluğu ortadan kalkan diğer uluslararası sergilerle benzer şekilde, 1911 Torino sergisinin binaları da tarihe gömülmüştür.

\section{Sonuç}

Osmanlı Devleti 1911 yılında İtalya Krallığı'nın kuruluşunun 50. yılı kapsamında düzenlenen sergilerden Roma ve Torino sergilerine katılmayı amaçlamış ancak zaman kısıtlılığı ve maddi sıkıtılar gibi nedenlerle yalnızca Torino sergisine katılabilmiştir. Torino sergisi için inşa edilen Osmanlı pavyonu, daha önce İstanbul ve Sofya'da uygulamalar yapmış olan ve 1907 yılında İtalya'ya taşınan mimar Levon Güreğyan tarafından tasarlanmıştır. Güreğyan geçmişte yaptığı uygulamalarla paralel olarak Torino sergisi için tasarladığı yapıda tarihsel üslupları canlandıran bir yaklaşım tercih etmiştir. Bu tercih üzerinde sergi komisyonunun yönlendirici etkisi olmuştur. Osmanlı arşivinde bulunan, komisyona bir dönem başkanlık yapmış olan Seyfeddin Bey’in Roma sergisi ve olasılıkla Torino için de geçerli olan, Bursa Yeşil Cami gibi mimarisi ve süslemeleriyle ön planda olan bir yapının model olarak seçilmesi önerisinin okunabildiği belge bu anlamda önemlidir. Olasılıkla bu önerinin tesiriyle, Torino pavyonunun tasarımında, Yeşil Cami'nin ve diğer erken Osmanlı yapılarının ilham kaynağı olduğu, 1860'tan sonra gelişen Oryantalizm anlayışı belirleyici olmuştur. Bu anlamda pavyonun Ulusal Mimarlık Akımı'nın yükselmekte olduğu bir dönemde, Tanzimat sonrası oluşan mimarlık söylemi ile iletişim kurduğu söylenebilir. Bu söylem, modern ve milli bir mimari kimlik oluşturma idealiyle, erken Osmanlı döneminin prestijli yapıları ile Magrip-Endülüs bölgelerinin ağırlık kazandığı Batı kaynaklı Oryantalist yapılardan devşirilen detayların sentezlendiği “Osmanlı Oryantalizmi”ni şekillendirmiştir. Uluslararası sergilerin Osmanlı temsillerinde bu mimari sentezin kullanımı gelenek haline gelmiştir. Güreğyan bu tasarımında, Usul-i Mimari-i Osmani'nin idealize ettiği Abdülaziz döneminin Çırağan Sarayı, Pertevniyal Valide Sultan Camii ve bunlarla aynı üslubu izleyen Yıldız Hamidiye Camii (1885-1886) gibi yapılardan beslenmiştir. Böylece Oryantalist üslubun bu geç örneğiyle, bir yandan devletin dişarıya karşı mimari kültürünü biçimlendirmiş, diğer yandan Batılıların hayalindeki "gizemli Doğu” imgesini canlandıran bir dekor oluşturmuştur. Torino sergisi örneği, 19. yüzyılda kurgulanan, Batı ve Batı-dışı kültürler olmak üzere iki ana eksende gelişen sergi düzeninin 20. yüzyılda da devam ettiğini göstermektedir. Cumhuriyet Dönemi'nde ise, Uluslararası sergilerde sunulan "milli mimari” anlayışı Neo-Osmanlı formları ile modern çizgileri birleştiren bir yaklaşımla temsil edilecektir. 
Hakem Değerlendirmesi: Dış bağımsız.

Çıkar Çatışması: Yazar çıkar çatışması bildirmemiştir.

Finansal Destek: Yazar bu çalışma için finansal destek almadığını beyan etmiştir.

Peer-review: Externally peer-reviewed.

Conflict of Interest: The author has no conflict of interest to declare

Grant Support: The author declared that this study has received no financial support.

\section{Kaynakça/References}

Adıgüzel, Hatice. “Bir Tasarımın İzinde: Yeni Bulgular Işı̆̆ında Raimondo D’Aronco'nun İlk İstanbul Projesi Dersaadet Ziraat ve Sanayi Sergi-i Umumisi." METU Journal of the Faculty of Architecture 36/1 (2019): 157-182.

Akçura, Gökhan. Türkiye Sergicilik ve Fuarcılık Tarihi. İstanbul: Tarih Vakfı Yurt Yayınları, 2009.

Akyıldız, Ali. "Yusuf İzzeddin Efendi." TDV İslâm Ansiklopedisi. 44. İstanbul: Türkiye Diyanet Vakfi Yayınları, 2014, 13-16.

Allwood, John. The Great Exhibitions. London: Studio Vista, 1977.

Annuaire Oriental du Commerce de L'industrie, de L'administration et de la Magistrature.

Constantinople: Cervati Freres \& Cie, 1896.

Annuaire Oriental du Commerce de L'industrie, de L'administration et de la Magistrature.

Constantinople: Cervati Freres \& Cie, 1898.

Annuaire Oriental du Commerce de L'industrie, de L'administration et de la Magistrature.

Constantinople: The Annuaire Oriental \& Printing Company Limited,1900.

Annuaire Oriental du Commerce de L'industrie, de L'administration et de la Magistrature.

Constantinople: The Annuaire Oriental \& Printing Company Limited, 1901.

Annuaire Oriental du Commerce de L'industrie, de L'administration et de la Magistrature.

Constantinople: The Annuaire Oriental \& Printing Company Limited,1902.

Annuaire Oriental du Commerce de L'industrie, de L'administration et de la Magistrature.

Constantinople: The Annuaire Oriental \& Printing Company Limited, 1903.

Annuaire Oriental du Commerce de L'industrie, de L'administration et de la Magistrature.

Constantinople: The Annuaire Oriental \& Printing Company Limited,1904.

Annuaire Oriental du Commerce de L'industrie, de L'administration et de la Magistrature.

Constantinople: The Annuaire Oriental \& Printing Company Limited,1909.

Annuaire Oriental du Commerce de L'industrie, de L'administration et de la Magistrature. Constantinople: Alfred Rizzo, 1921.

Aoki, Miyuki. "Léon Parvillée: Osmanlı Modernleşmesinin Eşiğinde Bir Fransız Sanatçı.” Doktora Tezi, İstanbul Teknik Üniversitesi, 2002.

Ayverdi, Ekrem Hakkı ve İbrahim Aydın Yüksel. İlk 250 Senenin Osmanlı Mimarisi. İstanbul: İstanbul Fatih Cemiyeti Yayınları, 1976.

Başaran, Bengi. “1893 Chicago Kolomb Dünya Sergisi’nde Osmanlı Temsili.” Doktora Tezi, İstanbul Teknik Üniversitesi, 2015. 
Borgo Medievale. "Dall’Esposizione al Museo.” Erişim 16 Eylül 2021. http://www. borgomedievaletorino.it/il-borgo/come-nasce-borgo-medievale/da-esposizione-a-museo/ .

Bozdoğan, Sibel. Modernizm ve Ulusun İnşası: Erken Cumhuriyet Türkiyesi’nde Mimari Kültür. İstanbul: Metis Yayınları, 2002.

Buscioni, Maria Cristina. Esposizioni e "Stile Nazionale" (1861-1925): Il Linguaggio dell'Architettura nei Padiglioni Italiani delle Grandi Kermesses Nazionali ed Internazionali. Firenze: Alinea Editrice, 1990.

Çark, Yervant G. Türk Devleti Hizmetinde Ermeniler, 1453-1953. İstanbul: Yeni Matbaa, 1953.

Çelik, Zeynep. Şarkın Sergilenişi: 19. Yüzyıl Dünya Fuarlarında İslam Mimarisi. İstanbul: Tarih Vakfi Yurt Yayınları, 2005.

De Luca, Pasquale. “All’Esposizione Internazionale di Torino.” Emporium 34/ 199 (1911): 37-52.

De Luca, Pasquale. “L'Arte all'Esposizione di Torino.” Emporium 34/ 202 (1911): 271-289.

Derin, Sevil. "1904 St. Louis Dünya Fuarı ve Osmanlı Temsiliyeti: Celal Esad Arseven Sergisi." Art-Sanat 13 (2020): 87-116.

Deringil, Selim. İktidarın Sembolleri ve İdeoloji: II. Abdülhamid Dönemi (1876-1909). İstanbul: Doğan Kitap, 2014.

Edhem Pacha. Usul-i Mimari-i Osmani/L'Architecture Ottomane /Die Ottomanische Baukunst. İstanbul: y.y, 1873.

Ergüney, Yeşim Duygu ve Nuran Kara Pilehvarian. “Ondokuzuncu Yüzyıl Dünya Fuarlarında Osmanlı Temsiliyeti." Megaron 10/2 (2015): 224-240.

Ersoy, Ahmet. "Architecture and the Search for Ottoman Origins in the Tanzimat Period." Muqarnas 24 (2007): 117-139.

Ersoy, Ahmet. "Aykırı Binanın Saklı Kalfası: Hamidiye Camisi ve Nikolaos Tzelepis (Celebis)," Batılılaşan Ístanbul'un Rum Mimarları. Ed. Hasan Kuruyazıcı ve Eva Şarlak. İstanbul: Zoğrafyon Lisesi Mezunları Derneği, 2011, 104-117.

Ersoy, Ahmet. Architecture and the Late Ottoman Historical Imaginary: Reconfiguring the Architectural Past in a Modernizing Empire. Burlington: Ashgate, 2015.

Guida Pratica della Esposizione Internazionale di Torino, 1911. Torino: Ajassa \& Ferrato Editori, 1911.

Guida Ufficiale della Esposizione Internazionale: Torino 1911. Torino: Stabilimento Tipografico Dott. G. Momo, 1911.

Gurekian, Armen. Léon Gurekian Architetto. Treviso: G.S. Stampa di Asolo, 2010.

Gurekian's Home Page. Erişim 16 Eylül 2021. http://www.gurekian.com/index.html .

Hasol, Doğan. 20. Yüzyıl Türkiye Mimarlı̆̆ı. İstanbul: YEM Yayınları, 2017.

Işıklı, Aytaç. Türkiye Fuar Albümü: Osmanlı Dönemi. İstanbul: İstanbul Fuar Merkezi Yayınları, 2012.

İnal, İbnülemin Mahmut Kemal. Osmanlı Devrinde Son Sadrazamlar. 4. cilt, İstanbul: Dergah Yayınları, 1982.

Kuban, Doğan. Osmanlı Mimarisi. İstanbul: YEM Yayınları, 2007.

Kuneralp, Sinan. "Palazzo Gamberini'den Osmanl1-İtalyan ilişkilerine Bir Bakış,” Palazzo Gamberini: Türkiye'nin Roma Büyükelçiliği. Haz. Arzu Karamani Pekin. İstanbul: Vehbi Koç Vakfi, 2013, 16-46. 
Kurşun, Zekeriya. “İbrahim Hakkı Paşa (1863-1918) Osmanlı Sadrazamı.” TDV İslâm Ansiklopedisi. 21. İstanbul: Türkiye Diyanet Vakfı Yayınları, 2000, 311-314.

Kuruyazıc1, Hasan. “İstanbul'un Unutulmuş Mimarlar1-4.” Ístanbul 34 (2000): 73-76.

Küçükerman, Önder. Anadolu'nun Geleneksel Halı ve Dokuma Sanatı Içinde Hereke Fabrikası: Saray'dan Hereke'ye Giden Yol. İstanbul: Sümerbank Yayınları, 1987.

La Guida Tricolore Rimborsabile di Torino e della Esposizione del 1911. Milano: F. De Rio, 1911.

Le Esposizioni di Roma e di Torino nel 1911 Descritte ed Illustrate. 10. Milano: Società Editrice Sonzogno, 1911.

Le Esposizioni del 1911: Torino, Roma, Firenze. Milano: Fratelli Treves, 1911.

L'Esposizione di Torino: Giornale Ufficiale Illustrato dell'Esposizione Internazionale delle Industrie e del Lavoro 1911, 25. Torino: Stabilimento Tipografico Momo, 1911.

Önsoy, Rıfat. “Osmanlı İmparatorluğu'nun Katıldığı İlk Uluslararası Sergiler ve Sergi-i Umumi-i Osmani (1863 İstanbul Sergisi).” Belleten 185 (1984):195-235.

Pamuk, Şevket. Osmanlı-Türkiye İktisadi Tarihi 1500-1914. İstanbul: İletişim Yayınları, 2017.

Pamukciyan, Kevork. Ermeni Kaynaklarindan Tarihe Katkılar-IV: Biyografileriyle Ermeniler. İstanbul: Aras Yayınc1lık, 2003.

Petrusa, Mariantonietta Picone, Maria Raffaela Pessolano ve Assunta Bianco. Le Grandi Esposizioni in Italia 1861-1911: La Competizione Culturale con l'Europa e la Ricerca dello Stile Nazionale. Napoli: Liguori, 1988.

Rigotti, Giorgio. 80 Anni di Architettura e di Arte: Annibale Rigotti Architetto 1870-1968, Maria Rigotti Calvi Pittrice 1874-1938. Torino: Tipografia Torinese Editrice, 1980.

Sakaoğlu, Necdet. "Yusuf İzzeddin Efendi." Yaşamları ve Yapıtlarıyla Osmanlılar Ansiklopedisi. 2. cilt. İstanbul: Yapı Kredi Yayınları, 1999, 683-684.

Saner, Turgut. 19. Yüzyıl İstanbul Mimarlı̆̆ında “Oryantalizm”. İstanbul: Pera Turizm ve Ticaret, 1998.

Şehbal 39. 1 May1s 1327 (14 Mayıs 1911), 297.

Şehbal 77. 15 Haziran 1329 (28 Haziran 1913), 95.

Şenyurt, Oya. "Geç 19. ve Erken 20. Yüzyılda İstanbul'da Etkinlik Göstermiş Bazı Ermeni Mimarlar.” Arredamento Mimarlı 11 (2002): 74-81.

Şenyurt, Oya. "II. Abdülhamid Döneminde Panislamist Siyasetin Mimaride Oksidentalist Temsiliyete Dönüşmesi Üzerine Bir Deneme.” Munzur Üniversitesi Sosyal Bilimler Dergisi 8/15 (2019): 9-32.

Tanyeli, Uğur. “ ‘İslam Mimarlığı’ Kavramına Eleştirel Bir Bakış.” Mimarlık 226 (1987): 52-54.

Tanyeli, Uğur. Mimarlı̆̆ın Aktörleri Türkiye, 1900-2000. İstanbul: Garanti Galeri, 2007.

Toprak, Zafer. Türkiye'de Milli İktisat 1908-1918. İstanbul: Türkiye İş Bankası Kültür Yayınları, 2019.

Tuğlacı, Pars. Tarih Boyunca İstanbul Adaları, 1. cilt. İstanbul: Cem Yayınevi, 1989.

Turin 1911: The World's Fair in Italy. "Participating Countries.” Erişim 16 Eylül 2021. https:// italyworldsfairs.org/basic/NS/Nation_States .

Uras, Büke. Balyanlar: Osmanlı Mimarlı̆̆ ve Balyan Arşivi. İstanbul: Korpus Kültür ve Sanat Yayıncilik, 2020. 
Wharton, Alyson. “Armenian Architects And 'Other' Revivalism," Revival: Memories, Identities, Utopias. Ed. Ayla Lepine, Matt Lodder ve Rosalind McKever. London: The Courtauld Institute of Art, 2015, 130-167.

Wharton-Durgaryan, Alyson. “' I Understood that He Is Entrusted to Serve Some Great Business Undertaking': Armenian Architects Reshaping the Ottoman East in the Hamidian Era (18761909)," Art, Trade and Culture in the Islamic World and Beyond From the Fatimids to the Mughals. Ed. Alison Ohta, J.M. Rogers ve Rosalind Wade Haddon. London: Gingko Library, 2016, 124-137.

Yazıc1, Nurcan. “Osmanlı'nın İlk Mimarlık Kitabı: Usul-u Mimari-i Osmani.” Arkitekt 497 (2003): 12-19.

Yazıc1, Nurcan. “Uluslararası Sergilerde Osmanlı Mimarisi'nin Sunumu.” Arkitekt 500 (2004): 1830.

Yazıc1, Nurcan. “Atmeydanı'nda İlk Osmanlı Sergi Binası ve Mimar Bourgeois-Parvillée-Montani İşbirliği," Hipodrom/Atmeydanı: İstanbul'un Tarih Sahnesi. Ed. Ekrem Işın. İstanbul: Pera Müzesi Yayınları, 2010, 128-151.

Başbakanlık Osmanlı Arşivi (BOA). Bab-1 Ali Evrak Odası (BEO) 3806/285423-8, M 3 Şubat 1909.

Başkanlık Osmanlı Arşivi (BOA). Bab-1 Ali Evrak Odası (BEO) 3733/ 279934-5, R 23 Kanunisani 1910 (23 Ocak 1910).

Başkanlık Osmanlı Arşivi (BOA). Bab-1 Ali Evrak Odası (BEO) 3733/ 279934, R 4 Safer 1328 (16 Şubat 1910).

Başkanlık Osmanlı Arşivi (BOA). Bab-1 Ali Evrak Odası (BEO) 3806/285423-2, H 17 Ramazan 1328/R 8 Eylül 1326 (21 Eylül 1910).

Başkanlık Osmanlı Arşivi (BOA). Bab-1 Ali Evrak Odası (BEO) 3834/287489-1, H 8 Zilhicce 1328/R 27 Teşrinievvel 1326 (11 Aralık 1910).

Başkanlık Osmanlı Arşivi (BOA). Bab-1 Ali Evrak Odası (BEO) 3835/287570-2, H 27 Zilhicce 1328/R 16 Kanunuevvel 1326 (30 Aralık 1910).

Başkanlık Osmanlı Arşivi (BOA). Dahiliye İdare (DH.ID.) 108/11-7, M 13 Şubat 1911.

Başkanlık Osmanlı Arşivi (BOA). Dahiliye İdare (DH.ID.) 108/11-1, R 2 Şubat 1326 (15 Şubat 1911).

Başkanlık Osmanlı Arşivi (BOA). Dahiliye İdare (DH.İD.) 108/11-3, R 7 Mart 1327 (20 Mart 1911).

Başkanlık Osmanlı Arşivi (BOA). Hariciye Nezareti İdare (HR.İD.) 1225/39-1, M 12 Şubat 1908.

Başkanlık Osmanlı Arşivi (BOA). Hariciye Nezareti İdare (HR. İD.)1225/34-1, M 3 Şubat 1909.

Başkanlık Osmanlı Arşivi (BOA). Hariciye Nezareti İdare (HR.İD.) 1225/34-7, M 9 Haziran 1909.

Başkanlık Osmanlı Arşivi (BOA). Hariciye Nezareti İdare (HR.İD.) 1225/38-1, M 23 Ocak 1910.

Başkanlık Osmanlı Arşivi (BOA). Hariciye Nezareti İdare (HR.İD.) 1225/38-2, M 29 Ocak 1910.

Başkanlık Osmanlı Arşivi (BOA). İrade Meclis-i Mahsus (İ. MMS.) 136/7-1, H 7 Safer 1329 / R 25 Kanunisani 1326 (7 Şubat 1911).

Başkanlık Osmanlı Arşivi (BOA). İrade Meclis-i Mahsus (İ. MMS.) 136/7-2, H Muharrem/Safer 1329 / R Kanunisani 1326 (Ocak/Şubat 1911).

Başkanlık Osmanlı Arşivi (BOA). Meclis-i Vükela Mazbataları (MV.) 139/17-1, H 29 Rebiulevvel 1328/ R 28 Mart 1326 (10 Nisan 1910).

Salt Araştırma. Fotoğraf ve Kartpostal Arşivi. Katalog Numara: AHTOR001. 
